\title{
CLASSIFYING AND MAPPING DIVERSITY IN A SPECIES POOR SYSTEM: \\ THE MANGROVE META-COMMUNITY OF LAGUNA CHACAHUA NATIONAL PARK, OAXACA, MEXICO:
}

\author{
A Thesis \\ Presented to \\ The Faculty of California Polytechnic University \\ San Luis Obispo
}

\author{
In Partial Fulfillment \\ of the Requirements for the Degree \\ Master of Science in Biology
}

by

Elizabeth Kay Weisgerber

June 2011 
(C) 2011

Elizabeth Kay Weisgerber

ALL RIGHTS RESERVED 


\section{COMMITTEE MEMBERSHIP}

TITLE:

AUTHOR:

DATE SUBMITTED: June 2011

COMMITTEE CHAIR: $\quad$ Matt Ritter, Professor

COMMITTEE MEMBER: David Yun, GISP

COMMITTEE MEMBER: Charles Knight, Professor 


\section{ABSTRACT \\ Classifying and Mapping Diversity in a Species-Poor System: the mangrove meta- community of Laguna Chacahua National Park, Oaxaca, Mexico \\ by}

Elizabeth Kay Weisgerber

Both field transects and imagery grid plots were analyzed with the goal of creating a community classification map for the mangrove forest of Parque Nacional Lagunas de Chacahua. In total, data was collected in 49 sites throughout the park, recording measures such as $\mathrm{DBH}$, basal area, estimated dominance, frequency, cover and relative dominance. Field location were marked and georeferenced with a GPS and grid plots overlaid on satellite imagery of the park were generated via a random number table. Species attributes delineating the identifiable features for each dominant species within Chacahua were noted and used to recognize patterns in species assemblages. fourteen distinct 'sub-communities' within the mangrove meta-community were recognized using this data and verified with 165 field photos. Relative dominance values were compared between field and grid data. These data revealed a similar pattern with Rhizophora mangle being most dominant under each method. Avicennia germinans was second in relative dominance, Laguncularia racemosa a close third while Conocarpus erectus was rarely found, most likely due to over-harvesting.

Rapid degradation of mangrove forests is occurring on a global scale.

Understanding the complex dynamics that occur within the mangrove meta-community is essential to its conservation. Vegetation maps are essential tool in monitoring changes 
throught the mangrove but are rarely of sufficient detail for everyday use. Generating highly detailed vegetation maps in a cost-effective and timely manner is an important step for their conservation, particularly in developing countries. This study demonstrates methods and techniques for producing a vegetation map that portrays the level of complexity that exists within the species-poor mangrove environment. This map will be donated to the management team of Parque Nacional Lagunas de Chacahua to better aid in management. 
Keywords: phytosociology, ArcMap, mangal, meta-community, interpretation key, remote sensing, supervised classification, vegetation classification 


\section{ACKNOWLEDGMENTS}

I would like to thank my advisor Matt Ritter, for his generous assistance and advisorship particularly in Oaxaca. David Yun, for his many hours of technical support and the rest of my professors who have made small but very significant contributions to this study. Special thanks to my Father for the continuous words of encouragement. 


\section{TABLE OF CONTENTS}

\section{Page}

LIST OF TABLES vii

LIST OF FIGURES viii

CHAPTER

1. INTRODUCTION 1

Definition of Problem 2

Key Terms

2. BACKGROUND and LITERATURE 6

$\begin{array}{ll}\text { Mangrove Biology } & 6\end{array}$

Mangrove Distribution $\quad 9$

Defining and Classifying Mangrove Communities 10

$\begin{array}{ll}\text { Mangrove Mapping } & 16\end{array}$

$\begin{array}{ll}\text { Summary } & 22\end{array}$

3. MANGROVE CLASSIFICATION AND MAPPING IN LAGUNAS DE CHACAHUA NATIONAL PARK, OAXACA, MEXICO 24

$\begin{array}{ll}\text { 3.1 METHODS } & 24\end{array}$

Description of Study Area $\quad 24$

Methodological Framework $\quad 26$

Community Classification 31

3.2 RESULTS and DISCUSSION 32

$\begin{array}{ll}3.3 \text { CONCLUSION } & 39\end{array}$ 


\section{LIST OF TABLES}

Table

Page

1. Mangrove forest cover (ha) among the three main lagoons of Chacahua National Park ........................................................... 25

2. Attributes for determining species identity in imagery analysis..................30 


\section{LIST OF FIGURES}

Figure

Page

1. Geographic location of Lagunas de Chacahua National Park................. 25

2. Methodological framework of the scientific process used in this study.......... 26

3. Field transect locations indicated by GPS points. Solid line represents

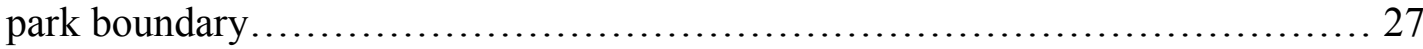

4. Example of transect design. Baseline was $60 \mathrm{~m}$ in length. Perpendicular

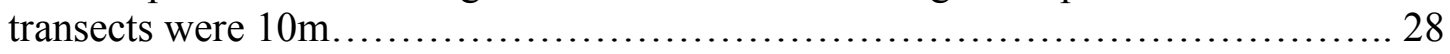

5. Grid plot analysis using random numbers. Each square is $100 \mathrm{~m} \times 100 \mathrm{~m} \ldots \ldots \ldots . .31$

6. The nineteen cover classes of Laguna Chacahua National

Park ......................................................, 35

7. Number of hectares in which each species was dominant.................... 36

8. Harvested Conocarpus erectus found at site S12A........................ 36

9. Vegetation classes of Laguna Chacahua. Nine of fourteen classes were observed. 37

10. Vegetation classes of Laguna Salina. Ten of the fourteen classes were found in

this lagoon............................................................. 38

11. Vegetation classes of Laguna Pastoria. Seven of the fourteen classes were recorded in this lagoon...................................................... 39

12. Mangrove community coverage in Hectares. $\mathrm{JAF}=$ Juvenile Avicennia fringe, $\mathrm{JAH}=$ Juvenile Avicennia hammock, JALH = Juvenile Avicennia Laguncularia hammock, JALF= Juvenile Avicennia Laguncularia Fringe, MCAFF= Mature Conocarpus Avicennia Fringe Forest, $\mathrm{MAF}=$, Mature Avicennia Fringe, $\mathrm{MLB}=$ Mature Laguncularia Basin, MLH= Mature Laguncularia Hammock, $\mathrm{MRH}=$ Mature Rhizophora Hammock, MRMXF= Mature Rhizophora mix Fringe, $\mathrm{MRO}=$ Mature Rhizophora Overwash, MARALF= Mixed Age Rhizophora Avicennia Laguncularia Fringe, MARLH= Mature Avicennia Rhizophora Laguncularia Hammock.

13. Comparison of field and grid plot relative dominance values to determine community classification. In both techniques $R$. mangle, is the most dominant followed by, A. germinans, L. racemosa and lastly Conocarpus erectus 


\section{CHAPTER I: INTRODUCTION}

\section{Problem Definition}

Playing an emblematic role in tropical and semi-tropical wetlands throughout the world, mangrove forests have earned global household recognition. Mangrove forests are a particularly important natural resource in terms of ecosystem services they provide to humans, playing an important role in supplying the world's fisheries. Many fish and shellfish species use mangrove lagoons as habitat or nursery sites for their young at the most critical life stage (e.g. larvae and juvenile stages) then moving out to other ecosystems as adults (Robertson and Duke, 1990; Ogden, 1997; Barletta-Bergan et al., 2002; Nagelkerken et al., 2002; Crona and Rönnbäck, 2007; Serafy and Araújo, 2007; Walters et al., 2008). Migratory birds, fish and mammals also use mangroves as important stopover sites along their journey (Saenger et al., 1983). Other ecosystem services provided by mangroves include biofiltration supported by high photosynthetic capacity, water quality control, nutrient cycling, and soil formation. The abrupt ecotone between a mangrove forest and the adjacent vegetative communities acts as a potential biocontrol, buffering the invasive potential of exotic plants dispersed aquatically. One critical function supporting all these services is that mangroves effectively retard water flow, mainly as a function of the trees' three dimensional structural complexity and the complex topographical features of channels and creeks. This enables efficient trapping of suspended and particulate matter, which can lead to land accretion buffering against potential sea level rise in the future (Walters et al., 2008). These ecosystem services indirectly benefit humans. 
Mangroves also provide many direct services such as non-timber forest products (NTFP's) and lumber for building. Many small coastal communities in the tropics, in particular those that are geographically isolated, are economically challenged and rely on harvesting of local resources for their livelihood. Four population centers exist in Laguna Chacahua National Park, two of which are only accessible by boat. The mangrove forests of Chacahua provide the local people with many NTFP's as well as material for building houses and fencing. Of the four true mangrove species found in Chacahua, Conocarpus erectus, commonly known as the buttonwood mangrove is the most desirable material for home construction due to its durability. Consequently, exploitation has occurred and mature specimens are rarely found in the park due to slow growth and generation time (Hernández and Espinosa, 1999). The twisted and irregular shaped of the less desirable Laguncularia racemosa (white mangrove) and Avicennia germinans (black mangrove) renders them useful primarily for fencing and handi-crafts (Huerta Garcia \& Frejomil, 2000). In addition, the flowers of black mangrove are widely used in tea making (Hernandez Cornejo et al., 2005). The red mangrove, Rhizophora mangle, contains very high levels of tannins thus burning long and hot which makes it most attractive for making charcoal or using directly as firewood (Huerta Garcia \& Frejomil, 2000). This high tannin content also makes the bark of red mangrove useful for dyeing and tanning (Walters et al., 2008). In Laguna Chacahua the flowers of the red mangrove are highly valued for making "mangrove honey" (Omar Hernandez de Luna, personal communication, June $\left.21^{\text {st }}, 2010\right)$.

The resource utilization and ecosystem services provided by mangrove forests contributes tremendous value to this ecosystem. As Walters and colleagues (2008) point 
out, there is an increasing number of investigations in local resource utilization and ecosystem service valuation of mangroves. However, these studies are concentrated in Southeast Asia, East Africa and India, leaving significant mangrove regions such as Malaysia, Indonesia, Central America and Mexico understudied. Human reliance and anthropogenic disturbance of mangroves make the need to understand their ecology even more pertinent for their continued existence and use.

Despite their importance and global recognition, mangrove forests are in rapid decline. The most recent study of their worldwide distribution reports mangrove forest area to be $137,716 \mathrm{~km}^{2}$, accounting for only $0.7 \%$ of tropical forests, a figure $12 \%$ lower than the most recent estimate by the Food and Agriculture Organization of the United Nations (FAO) in 2007 (Giri et al., 2011). This discrepancy is due to recent improvement in remote sensing capability over the last decade. Although this data provides us with information for mangrove forest distribution and coverage on a global scale, it does not indicate the condition these forests are in. Knowing the quality of a forest allows biologists to assess its habitat suitability for many species as its carbon fixing value. The data also does not indicate which species constitute what we so frequently generalize as a "mangrove", or more specifically as the classic mangrove with the large arching prop roots and thick, leathery green leaves better known as the Red mangrove (Rhizophora mangle). In fact a mangrove is a word to describe a group of plants composed of various tree species as distantly related as an oak (Quercus spp.) is to a maple (Acer spp).

Being able to monitor changes in the plant sub-communities that exist within the larger meta-community of the mangrove forest is an important element in understanding how a mangrove forest is or is not changing. Observing and recognizing these changes over time can only be accomplished through a detailed classification scheme that identifies one sub-community from another. Displaying these classified sub-communities 
on a vegetation map is the best way to assess how the species composition, condition and quality of a forest changes over time. Vegetation maps are an immensely valuable tool to biologists. However, in many species-poor plant communities such as a mangrove these communities are generalized as one vegetation type (mangrove), either due to lack of surface area coverage relative to adjacent, more complex communities or from lack of resources to groundtruth or obtain expensive aerial imagery. This generalization makes good monitoring very difficult and changes in the species composition difficult to track. In a system that lacks diversity it is important recognize the other features that create niches and make habitats unique. New technology and the methodology described in this study make it possible to create highly detailed vegetation maps that reflect these niches, quickly and cost-effectively.

In this study I aim to combine Bing ${ }^{\mathrm{TM}}$ Aerial Imagery with field collected data to create mangrove community classifications that will be digitized into a GIS, creating a vegetation map for the mangrove forest of Lagunas de Chacahua National Park in Oaxaca, Mexico. 
Phytosociology: The study of vegetation through its floristic composition, structure, development and distribution.

ArcMap: ESRI's ArcGIS desktop software that is used to view, edit, and analyze geographic data.

Bing Aerial Imagery: Licensed in 2010 with ESRI to use multiple remote sensing data from various providers to construct digital images at many scales, available through ESRI.

Meta-community: Can be described in many ways but for the purpose of this study is defined as the larger mangrove plant community in a particular geographic area, where sub-communities can be found interconnected and composing the larger metacommunity.

Mangal: Alternative term to describe a mangrove forest and all it encompasses Vegetation mapping: Delineating spatial boundaries between plant cover types on a broad or detailed scale and displaying the results in a geographical representation. Interpretation keys: Decision key developed by Verheyden and colleagues for visual interpretation of remote sensing images.

Supervised Classification: A technique used to create training samples that 'train' a computer to recognize samples in images with the same attribute input as the training sample.

Remote sensing: The science of identifying objects or spatial patterns at a distance.

CHAPTER II: BACKGROUND and LITERATURE

\section{Mangrove Biology}


Physiologically one of the most fascinating groups of plants, mangroves are salttolerant trees or shrubs that dominate the intertidal zone along tropical coastlines (Tomlinson, 1986). The mangrove forests of Pacific Mexico are dominated by Rhizophora mangle, Laguncularia racemosa, Avicennia germinans, and Conocarpus erectus, (Pool et al., 1977). Each of these species survival is dependent upon varying degrees of freshwater influx (Tomlinson 1986). Salinity levels vary throughout portions of lagoon systems with higher levels existing more seaward and lower salinity levels in the landward regions. Sedimentation and litterfall create highly anoxic environments leading to more anatomical developments adapted to succeeding in those conditions. Survival in this brackish environment has been dependent upon the evolution of both morphological and anatomical features. In general for each of the mangrove species regulation of ion uptake and transport, as well as salt secretion by glands allows mangroves to cope with high salinity levels while maintaining favorable water and carbon balance. Because water deficits can occur in such a saline environment the intracellular solute concentration can be increased by this uptake in ions then increases the tolerance to water deficiency. This results in the decrease in osmotic potential allowing mangroves to lower their xylem water potential much lower than that of the surrounding seawater. This stimulates the positive uptake of water by the roots, maintaining turgor pressure, and preventing cavitation at low soil water potential.

The red mangrove has morphological, physiological and reproductive characteristics, which contribute to the cause of its predominant distribution. This species is easily recognized by the most obvious morphological adaptation to an estuarine system. Large root structures termed "prop roots" rise out of the water in net like fashion leading to the main trunk, stabilizing the tree in region 1 where tidal fluctuation is greatest. The success of reproduction has been shown to be influenced by physiological 
factors such a salt preparation by viviparous seedlings. Vivipary is a rare condition where the seed germinates and becomes a seedling while still attached to the parent tree. A study conducted by Smith and Snedaker (1995) provided evidence of salinity preparation in Rhizophora mangle seedlings. Seedlings in their viviparous state were collected from parents located in two areas of different salinity, a high salinity (36\%) and low salinity (5\%). These seedlings were placed in both environments and allowed to grow. The results indicated that growth rates where much higher for the seedlings originating from the high saline environment when compared to seedlings originating from the same concentration as treatment (5\%). A possible explanation for this is the activation of certain enzymes and metabolic processes under high $\mathrm{NaCl}$ conditions (Cowan \& Rose 1991). Interestingly Smith and Snedaker also found that indices of root growth were initially higher in low salinities becoming insignificant over time while the indices for stem and leaf growth were obviously reduced throughout their entire experiment. One of the first studies concerning the effects of salinity on seedling growth was carried out by Pannier in 1962. Pannier was able to show the existence of an osmotic barrier between cotyledonary body and the seed integument of the parent / seedling junction, and that $\mathrm{NaCl}$ concentrations in the propagule are maintained at relatively low levels compared to the parent tree. This also suggested that chloride tolerance is developed gradually over the maturation of the seedling (Smith and Snedaker 1995).

Physiological adaptations to elevated $\mathrm{CO} 2$ have also been shown to occur in $R$. mangle demonstrating the apparent plasticity in this species not only in morphology but also in physiology. Farnsworth and colleagues investigated this subject finding that stomatal density decreased as epidermal cells enlarged in elevated $\mathrm{CO} 2$. They also found that this species was able to reproduce in 1 year (normal reproductive initiation begins after 3 years). This indicated that elevated $\mathrm{CO} 2$ appeared to accelerate maturation as well 
as growth. Another physiological adaptation to saline conditions in Red mangrove is the ability to accumulate excess salts not metabolized, in the upper leaves, then shedding those leaves via an abscission point in the petiole of the leaf (Tomlinson 1986).

Though not nearly as many studies have been conducted surrounding the physiological adaptations of the black mangrove (A. germinans) this plant also contains certain attributes that make it an interesting model for halophytic plants. The cellular adaptations in the leaves of the black mangrove have particularly special characteristics for studying salt water tolerance. This species is known to have the highest tolerance of all mangroves to hypersaline conditions and tolerates large salinity fluctuations (Tomlinson 1986). Three dominant mechanisms for black mangrove enable this high tolerance, deriving from salt exclusion in roots, intracellular salt accumulation in leaves and roots and the excretion of theses salts via the leaf glands. The adaxial epidermis of black mangrove lacks stomata and has a relatively thick cuticle, being subtended by four to five layers of hyperdermal cells.

A study conducted by Balsamo and Thomson (1995) found a significant increase in cation flux in epidermal regions where salt glands are more numerous indicating a localized transportation process facilitating greater efficiency.

\section{Mangrove Distribution}

Mangrove forests are a comparatively species-poor grouping of plants; however, because there are often times only 1 or 2 species from a single family found in this system, it is floristically quite diverse. Kathiresan and Bingham (2001) have derived the most modern taxonomic list to date with 65 species in 22 genera of 16 families. Highly 
productive mangrove forests are found in 124 countries located between $30^{\circ} \mathrm{N}$ and $30^{\circ} \mathrm{S}$, covering up to $75 \%$ of tropical and subtropical shorelines. In the Americas it has, on the Atlantic side, a wide distribution to about latitude $25^{\circ} \mathrm{N}$ in Florida and to eastern Brazil. On the Pacific side it ranges from Mexico to northern Chile, where its southern range is limited by the cold dry climate. Rhizophora mangle contains the largest distribution of all existing mangrove species of the Americas.

On a habitat scale, differences in dominance and distribution also exist. Studies conducted by Lopez-Portillo and Ezcurra (1989) and Valdez (1994) showed that floristic and morphological gradients are defined by local geomorphological and hydrological conditions leading to an obvious distribution regime of the four dominant American species referred to as mangrove zonation. The concept of zonation patterns in mangroves was first presented as a consequence of age succession and disturbance regimes common to purely terrestrial forests. However this idea was challenged by others who argued that zonation pattern is due to changes in sedimentation and the tolerance of each species to varying types of sediment (Lopez-Portillo \& Ezcurra 1989). This hypothesis was further supported and refined by more modern day investigations such as the aforementioned studies conducted in 1989 and 1994. Mangrove zonation is specifically due to differences in soil salinity and nutrient loading contributed by sedimentation (Lopez-Portillo \& Ezcurra 1989). Watson (1928) in his classical studies of mangroves in the Malay Peninsula, defined zones as regional sets influenced by a combination of numbers and kinds of tidal inundation (inundation classes). More recently there has been consensus among several authorsthat the zonation patterns observed in mangrove forests are more complex and involve factors such as tidal fluctuation, interspecific relations and biotic interactions with other saltwater vegetation to be of primary importance. Perhaps there is no one defining factor that zonation can be attributed to and instead it is an equal 
proportion of combined factors that generate this community structure. No matter which it is, each of these four mangrove species renders specific physiological adaptations to its brackish environment.

\section{Defining and Classifying Mangrove Communities}

The ambiguity of the term mangrove often leads to the over-simplification of this plant community, despite the importance of its multi-genera composition. Many authors have previously attempted to define mangrove, and though these definitions have improved over the years they are often so broad there is room for plant species from other communities not associated with mangrove to be included.

One of the most classic definitions presented by Schimper in 1903 classified mangrove as a group of plants formed below the high tide mark. However as we now understand, mangroves can exist in areas above the high tide mark as well as areas that have no tidal influence at all (Lugo \& Snedaker, 1974). In 1972 Waisel provided a primarily taxonomic definition suggesting mangroves are halophytic species that belonged to twelve genera and eight families (Table 1). Some of these genera are found in only one region of the world. In tropical latitudes of the Americas only eight species have been identified, a depauperate comparison to the Indo-West-Pacific holding 36 reported species. More definitions exist but most authorities today, including the Food and Agricultural Organization of the United Nations (FAO), use the more detailed definition put forth by Tomlinson in 1986. According to Tomlinsons definition, mangrove, often referred to as mangal, is only a "true" mangrove species if it meets the following criteria:

1. Complete fidelity to the mangrove environment.

2. Morphological specializations for adaptation to the habitat. 
3. Plays a major role in the structure of the community and is capable of forming pure stands.

4. Physiological specialization for adaptation to the environment.

5. Taxonomic isolation from terrestrial relatives.

All of these definitions help us understand what constitutes a species we may encounter within the boundaries of a mangrove forest and scientists now have a better understanding of what is and what is not a mangrove plant. To add complexity, plants frequently found within the mangrove system but also found in terrestrial system are referred to as "mangrove associates". Two of the most common examples are Coco nucifera (Coconut Palm) and various species of Acacia. The button mangrove, Conocarpus erectus, is by some authors

Although a definition of what a mangrove exactly is, is useful to understand its geographic boundaries, it does not save us from the generalization of a very complex meta-community. To generalize a mangrove community is to imply it is both consistent and homogenous throughout and does not consider complex community dynamics that influence species composition and structure. A species-poor system such as the mangrove forests of the Americas, is a system where it is very easy to overlook ecological complexity. Under management scenarios it is both cost and time effective to produce management tools that can be prepared quickly and without a lot of resources. This is particularly true in developing countries where financial resources are already limited for such purposes and these countries are reliant on private external funds for assistance (Alpert,1996). Thus the vegetation maps produced (if any) by governmental agencies for national parks, preserves or land conservancies can be over-simplified and are more useful for navigational purposes than the monitoring of ecological change through time. 
Two approaches to classifying vegetation have been debated within the scientific community over the last century, physiognomic and taxonomic. In 1927, Gaussen (as cited in Muller, 1997) declared a taxonomic approach based on floristic parameters to be 'banned' by physiognomists while taxonomists considered physiognomy to be a 'nightmare' in community classification. The arguments over these two methods have lead the way to development of more refined scientific approaches. The Braun-Blanquet method (1964) was developed for botanists who preferred a phytosociological approach and is based on the identification of species, frequency of those species within an association and permits a high level of mapping accuracy. This classic approach begins with broad scale mapping through aerial photography, identifying large pattern distinctions between vegetation types. Then these photographs are analyzed and groundtruthed for taxonomic identification. However this system has been criticized for its inability to compare vegetation across a landscape. It also has extreme limitations in a species-poor system like a mangrove forest where each species is found almost everywhere in the surveyed habitat at the same time.

In response to this incapacity, botanists on the physiognomic side argued this approach to be applicable to vegetation classification on any scale (Kuchler, 1967). Descriptive parameters for describing life forms (e. g. broadleaf, evergreen, graminoids, deciduous dry forest), height, canopy coverage, geography etc. were capable of exact measurement and mathematically quantifiable (Muller, 1997). The inherent inaccessibility of mangrove forests has made assessment of the vegetative subcommunities within the larger meta-community previously very difficult or very expensive. Regions of the world where funding and resources are more abundant, such as Florida, have been more thoroughly documented. Study methods such as light helicopter fly-overs, and the building of boardwalks into dense areas were often employed 
techniques of the 1980's as interest in mangroves grew (Tomlinson 1986). Using these techniques research on forest structure as it related to physiognomic characterization became popular in the Caribbean region in the late 1970's and into the 1980's (Pool et al.,1977; Cintrón et al., 1980; Jiménez, 1981; Martínez, et al., 1979).

The physiognomic system of vegetation classification developed by Kuchler (1949) is useful in the study of mangroves because of its geographic and physiologic attributes as well as its adaptability to mapping for comparative purposes. As mentioned previously the inherent inaccessibility of the mangrove environment has historically made an assessment based on taxonomic associations more difficult. Lugo and Snedaker (1974) initially developed the original physiognomic classification for mangroves which was then slightly modified by Cintrón et. al. (1980) and included the following five classes:

Basin forest Found in inland areas, protected from direct coastal environments, these forest types persist in depressions with or without strong tidal velocity. In more seaward positions, $R$. mangle is dominant whereas in more landward positions less tidal influence can create hypersaline conditions leading to A. germinans dominance. In Chacahua, this forests type transitions to Acacia sp. scrub forest with increasing elevation.

Riverine forest These tall floodplain forests that exist along brackish drainage areas such as rivers, streams or even springs with tidal influx, can also become quite large due to higher nutrient levels from terrestrial runoff. Dominated once again by $R$. mangle and followed by a mixture of $A$. germinans and L. racemosa This forest type is particularly rare to non-existant in Chachahua (this author found none) due to the extensive dry season and limited sources of fresh water input. 
Fringe forest Exactly as its name implies this forest type occurs in fringes arranged neatly as strips along protected shorelines or islands. Elevations of these shorelines are generally higher than the mean high tide. The species that dominates along a fringe is determined by salinity level and tidal velocity.

Overwash forest Dominated by $R$. mangle, this forest type can be recognized as lowlying island tree clumps, or as long, narrow projections from the mainland. Due to their size, position and elevation, they are often "overwashed" during normal tide movements and have all debris that may have fallen or found itself there, washed out to inner bays where it becomes trapped in basins or the roots of fringe forests. Because they are cut off from the main forests system and are quite protected this forest type is important for bird rookeries.

Hammock forest Typically classified as a sub-category of the basin forest, this type also occurs in inland drainage areas that channel terrestrial runoff toward the sea. However the hammock forest occurs on slightly elevated terrain $(\sim 5-10 \mathrm{~cm})$ relative to the basin areas. In Chacahua, hammock forests are more common than basin forests. This could be a result of limited freshwater inputs and localized sedimentation caused by strong winds and hurricanes (CONABIO 2007).

These physiognomic categories have allowed mangrove forests around the world to be broadly analyzed and compared. However this physiognomic approach lacks taxonomic detail necessary to monitor change in a specified area over time. A 
combination of these two approaches could be beneficial in providing a more accurate assessment of a forest's individual complexity as well as its global comparability.

Recent advances in remote sensing have added a third dimension to the power of vegetation mapping. Photointerpretation has provided a coarse level of detail to vegetation maps and this has been supplemented by multispectral satellite imagery to make vegetation mapping possible over a larger extent and facilitated more quantitative approaches. These three approaches are complementary and in combination, have the ability to progress the mapping of mangrove communities in a more detailed and useful manner, quickly and efficiently. In the last decade, remote sensing technologies have rapidly advanced. The alarming rate of mangrove deforestation and the elucidation of this ecosystem's tremendous value have lead to a rush of investigations into creating better monitoring tools for these regions. These tools are important on global scales but even more important at the local level where mangrove managers and biologists are able to better assess changes in their forest through time.

\section{Mangrove Mapping}

For vegetation mappers, the quality of a vegetation map and hence its value, rests more heavily on the selected system of classification than on any other feature (Kuchler, 1967; Kuchler and Zonneveld, 1988; Muller, 1997). There is a sequence in which the first item (classification) is arrived at based on an arbitrary system, whereas the second item (vegetation map) expresses the first one cartographically (Kuchler, 1967). This distinction between classification and mapping is fundamental but is not really accounted for in the remote sensing geographic information system (GIS) approach, where there is semantic confusion between the two terms (Muller, 1997). 
The most extensively used classification system for mapping has been the BraunBlanquet phytosociologic approach. However as discussed previously several limitations in this method (not usable in species poor system unless modified) and in the inaccessibility of the mangrove environment itself make this approach less common in mangrove mapping than the physiognomic approach. Tremendous advances in remote sensing and computer technology have overcome many of the physical inaccessibility limitations of mangrove forests.

Since the 1970's field investigation and photointerpretation have been supplemented by multispectral satellite images which facilitated a more quantitative approach to vegetation (Muller, 1997). However the coarse resolution of satellite data has historically made it impossible to obtain data on individual communities and species. Remote sensing of vegetation, based on satellite data was useful in producing maps that covered broad landcover classes and biomass of large regions. This approach has lacked the detail necessary to aid managers on a local level in monitoring vegetational changes other than coverage. As noted by Wessman and colleagues (1991) little can be derived from reflectance measurements with regard to detailed species composition and distribution. It is the structure and composition that we must first ascertain and record as the secure basis of all subsequent knowledge. However as we know, physiognomists would disagree with this on a taxonomic level. It became obvious that a combination of the two would improve overall classification. Muller (1997) provides a brief synopsis of how botanists through the last century have attempted using environmental factors to improve their own vegetation classification techniques: e.g. exposure and altitude, temperature and rainfall water table level fluctuation, and soil moisture.

Another imperative factor that should also be considered when classifying vegetation, particularly in a wetland environment, is vegetation dynamics. The buffering 
properties of mangrove forests makes them inherently dynamic and creates a higher level of complexity than a more stable environment, despite the low species richness. Vegetation dynamics have been an early and central problem in vegetation mapping. As vegetation changes continuously over the same area, the temporal dimension of vegetation can be considered as an intrinsic characteristic of class definition. Despite this, the mapping of a dynamic system has been highly criticized by various authors who proclaim it is subjected to the observer's interpretation and observation at a single point in time. A key feature to relieving this bias is in the careful preparation of definitions for each community class that is created, such that other parties could take that methodology and update the data as needed through monitoring.

Classifying mangrove vegetation requires a comprehensive understanding of its ecological functions (e.g. successional patterns, species interactions, disturbance regime etc) and biotic and abiotic ecosystem processes. In addition mapping requires an exhaustive interpretation of the area under study as well as spatial representation of it. Even into the 90's, satellite data remained inadequate. Green et. al. (1993) noted that satellite data did not yet provide adequate resolution for purpose of modeling vegetation succession.

Including every one of these factors is not yet possible, but we are very close as modeling technologies and GIS system capabilities develop on a monthly basis. In the last decade advances such as hyperspectral imagery and powerful tools such as ArcGIS software have opened new doors for studies to investigate vegetation on a refined scale. According to Dahdouh-Guebas (et. al. 2002), GIS are widely used tools to digitize remotely sensed or cartographic data supported by various ground-truth data, which are geocoded using a global positioning system (GPS). GIS can be used to analyze the spatial characteristics of the data over various digital layers. For example, Vaiphasa and team 
(2006), used a post-classifier technique to improve the quality and accuracy of an already produced mangrove map. They added an additional layer of soil $\mathrm{pH}$ data into their GIS map. This significantly increased the mapping accuracy from $76.04 \%$ to $88.90 \%$. In addition, if sequential data are available quantification of spatial changes becomes possible through overlay analysis.

Such studies can be based on various sensors ranging from aerial photography to high and medium-resolution optical imagery and from hyperspectral data to active microwave (SAR) data. Kuenzer, (et. al. 2011) provides a comprehensive list stating remote sensing of mangroves provides important information for:

1. habitat inventories ( species composition, fitness, extent);

2. change detection and monitoring (coverage, land use, conservation and reforestation success, silviculture and aquaculture development);

3. ecosystem evaluation support;

4. productivity assessment;

5. regeneration capacity estimation;

6. multiple management requests (conservation, fisheries and aquaculture);

7. field survey planning;

8. water quality assessment

9. prompt information supply for disaster management

10. aid delivery to gain a better understanding of ecological and biological relations and processes, functions and dynamics.

One characteristic of remote sensing in mangrove forests that is important to point out, is the growth at a land-sea interface. The vegetation, soil and most importantly 
water greatly effect the spectral characterization of the image components. Blasco ( et. al., 1998) describes this as a major obstacle to rigorous radiometric characterization.

Textural and spectral characteristics of the canopy and leaves are the main features used to distinguish among mangrove communities. Their structural appearance, partially more homogenous or heterogeneous depends on several factors such as species composition, distribution pattern, growth form, density, and stand height (Ramsey and Jensen, 1996) The spectral variations of the canopy reflectance are a function of several optical properties such as leaf area index (LAI), background reflectance, and leaf inclination. The spectral signature of a single species is defined by age, vitality, phenological and physiological characteristics. Periodic climatic changes that influence the leaf dynamics of foliation and leaf senescence may also have an impact on spectral response. In 2005, Vaiphasa and team found there was difficulty in distinguishing one Rhizophora species from another due to similar spectral response. However, Wang and colleagues in 2008 observed a flush of young red mangrove leaves after seasonal rainfalls during the early wet season in Panama. This led them to believe that early wet season imagery may be more helpful due to the greater spectral distinction between species. Intertidal effects and soil type also influence a plants spectral translation (Blasco et al., 1998). Mangroves with lower stand density are significantly affected by intertidal effects, the sparser the vegetation canopies, the greater the influence of the ground surface. For example, in medium resolution imagery, the reflectance of mudflats in the background may result in a spectral signal that can easily be confused with urban residential areas (Gao, 1998).

Although the hyperspectral imagery is now quite popular, recent advances in the resolution of aerial photographs have generated a "comeback" for this remote sensing technique. It is very suitable for creating highly detailed vegetation maps at scales 
ranging from $1: 10,000$ to $1: 1,000$. Aerial imagery of the past used in mangrove mapping had scales of 1:50,000 (Verheyden et.al., 2002). The particular properties of high spatial resolution provided by aerial imagery allow the mapping of even narrow coastal areas with fringing stands, typical for these ecosystems, more possible. For this reason aerial imagery such as IKONOS is an excellent source for local to regional mapping. Larger scale than this would be too time-consuming and more generalized satellite imagery would then be needed.

Interpretation of aerial imagery, as mentioned previously, can be subjected to the bias of the observer. To correct for this potential bias Verheyden and colleagues developed an interpretive key to be used specifically for aerial imagery of mangrove forests. The interpretive key was designed to identify mangrove assemblages at the species level using the following attributes:

1. Color values: this attribute is regarded as a relative value, since light conditions can cause considerable differences. Neither the shaded side, nor the overexposed side of the crown is taken into consideration to determine the gray value (i.e. only the middle of the crown was used).

2. Texture: here defined as the internal structure detected in one crown (e.g. smooth, grainy).

3. The shape and size of the crown.

4. The presence or absence of a shaded side, as an indication of the density and shape of the canopy.

5. Structure and pattern: this was used in the determination of species assemblages defined as the way the tree canopies are distributed relative to one another. 
The fifth attribute was derived from Lillesand and Kiefers' (1994) 'pattern' attribute. To assess the accuracy of the keys Verheyden and colleagues performed a simple error analysis on the reliability of the keys to investigate whether the information obtained from fieldwork (more accurate but time consuming) can be obtained from (less time-consuming) aerial photograph interpretation.

Their analysis included:

1. The relative densities, as obtained from counting individual trees on the aerial photograph ('observed' values), were compared with those obtained from the fieldwork ('expected' values) for each of the vegetation assemblages using the $G$ test (Sokal and Rohlf, 1981; as cited in Verheyden et al., 2002).

2. The dominant species present (obtained from ground truthing data) within the species assemblage was compared with the dominant species determined from the aerial photograph analysis.

3. The delimitation of the species assemblages was incorporated into the error analysis. To accomplish this, the data obtained from the transects were visualized in a GIS and superimposed on the vegetation maps. The resulting map was visually inspected for species assemblages detected during fieldwork but not on the photographs.

The researchers found the interpretation keys to be quite reliable as the dominant genera in each species assemblage were successfully identified in most cases. However when comparing the relative density values, the results were insignificant. When comparing the identification of the dominant species from groundtruthing to that of aerial imagery they found that in most cases the dominant species was correctly identified. 
Verheyden and colleagues have produced an effective tool to aid future investigators who may not have access to expensive satellite imagery or programs to interpret them, a means of producing highly detailed, accurate and effective mangrove vegetation maps.

\section{Summary}

The rapid degradation juxtaposed against the immense value of mangrove forests makes their conservation imperative. To progress the strategies that make their conservation possible, scientists are developing new tools to better equip environmental managers with ways to understand and monitor the forests they supervise. Tracking changes in mangrove forest species composition, structure, fitness and other ecological factors is essential to maintain both the direct and indirect ecosystem services they provide us. Vegetation maps are one of the keys tools in this effort. Various vegetative classification schemes have been employed in mangrove mapping over the century, yet there is still no solid consensus on which mechanism is best. However we are getting closer to producing vegetation maps through inexpensive, quick and relatively easy methods that are highly detailed and accurate through a variety of remote sensing avenues. From aerial photography to the new hyperspectral imagery, it is perhaps a combination of these tools that will create the best maps and also the best methods of making the map.

Bing aerial imagery licensed by ESRI and new in 2011, uses a combination of hyperspectral, multi-spectral and aerial photography, changing with scale, to produce highly flexible and detailed imagery. The drawback lies in the licensing of ESRI software which is extremely expensive and out of reach for most agencies, particularly in developing countries. With the highest level of detail possible in high resolution aerial photos, collaborations between academic researchers and governmental agencies with 
this software are needed. In this study, I will use Bing ${ }^{\mathrm{TM}}$ Aerial imagery licensed through ESRI (ArcGIS Online: accessed 12/2010) to create a highly detailed vegetation map based on a novel classification approach, new methodology and use of methodology set forth by Verheyden and colleagues.

\section{CHAPTER 3: Mangrove Classification and Mapping in Lagunas de Chacahua National Park, Oaxaca, Mexico}

\subsection{METHODS}

Description of Study Area

Encompassing 17,424 hectares, Laguna Chacahua National Park is located on the Pacific Coast in the state of Oaxaca, Mexico. Situated at Latitude $15^{\circ} 58^{\prime} 37^{\prime \prime N}$ and Longitude $98^{\circ} 41^{\prime} 45^{\prime \prime} \mathrm{W}$ (Figure 1), the climate is characterized by a wet season from June through October with precipitation ranging from 700-2300mm . The mean annual temperatures range from minimum $14^{\circ} \mathrm{C}$ and maximum $28^{\circ} \mathrm{C}$. Water temperatures in the lagoons range from approximately $31^{\circ} \mathrm{C}$ in Chacahua to $32^{\circ} \mathrm{C}$ in Pastória, with salinity levels at 35ppm and 38ppm respectively, and average dissolved oxygen levels at $5.7 \mathrm{ml}^{-}$ ${ }^{1}$ and $4.1 \mathrm{ml} \mathrm{l}^{-1}$, respectively (Contreras et. al., 1997). Maximum tidal range is $1.5 \mathrm{~m}$ (NOAA meterological data, 2011). The Río Verde runs to the North of Chacahua and on years of heavy rain, will contribute inflow to the tributary channels that run into Chacahua. The mangrove forest area is spread across three connected lagoons: Laguna Salina, the most westerly and smallest in total area of the three, Laguna Chacahua, the middle lagoon containing the largest extent of mangroves, and the most easterly Laguna 
Pastoria, with the largest total area (Table 1).

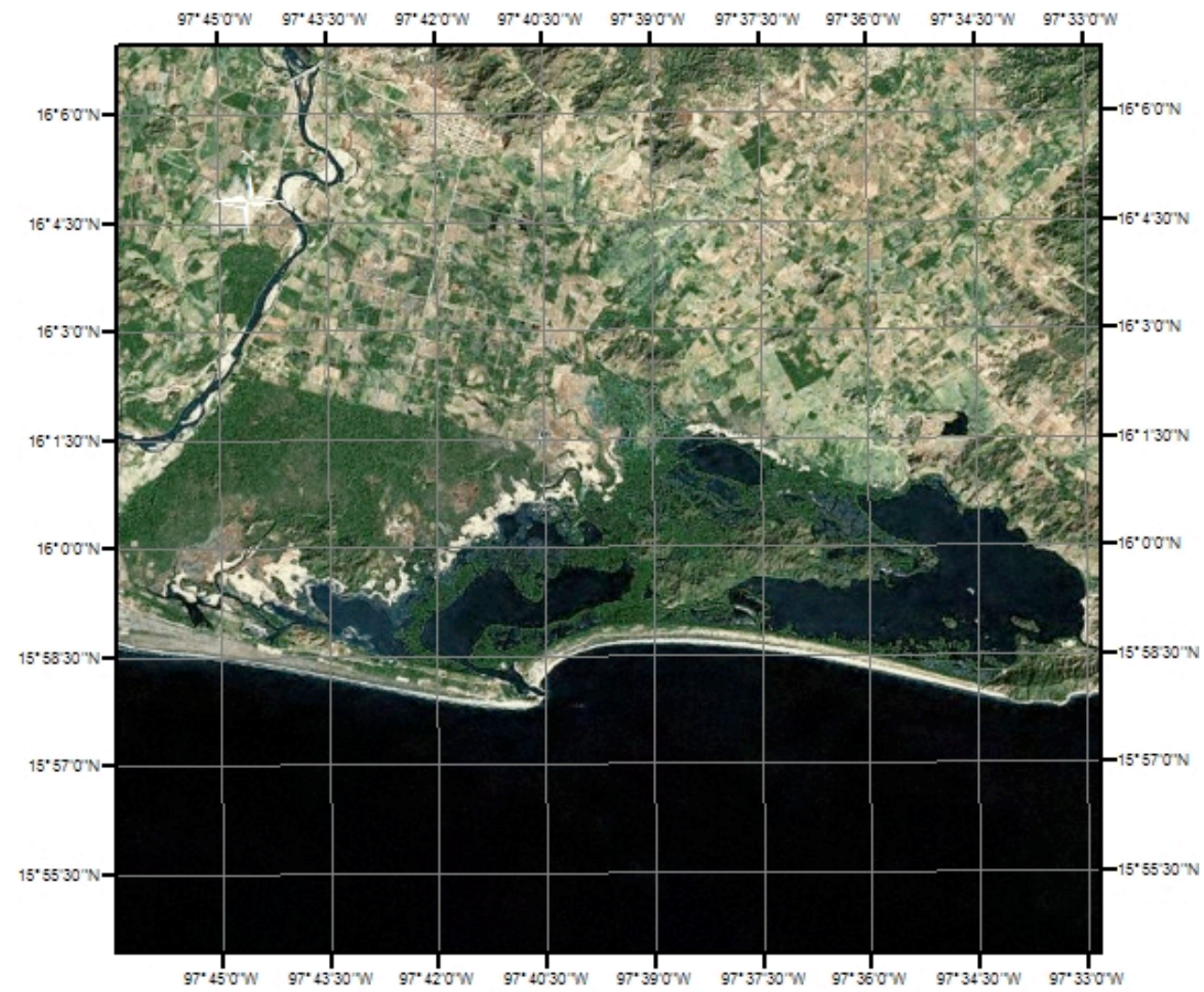

Fig. 1. Geographic location of Lagunas de Chacahua National Park.

Table 1. Mangrove forest cover (ha) among the three main lagoons of Chacahua National Park.

\begin{tabular}{lccc}
\hline $\begin{array}{l}\text { Name of lagoon } \\
\text { communities }\end{array}$ & Mangrove extent (ha) & $\begin{array}{l}\text { Total Area (ha) incl. } \\
\text { water and tidal flats }\end{array}$ & Mangrove \\
\hline Chacahua & 1,792 & 2,478 & 9 \\
Salina & 532 & 996 & 10 \\
Pastoria & 718 & 2,757 & 7 \\
\hline
\end{tabular}




\section{Methodological Framework}

The scientific process for this study contained two main phases: a field component for groundtruthing and mangrove data collection, and a laboratory phase for training, imagery interpretation, community classification and finally a vegetation map creation (Figure 2).

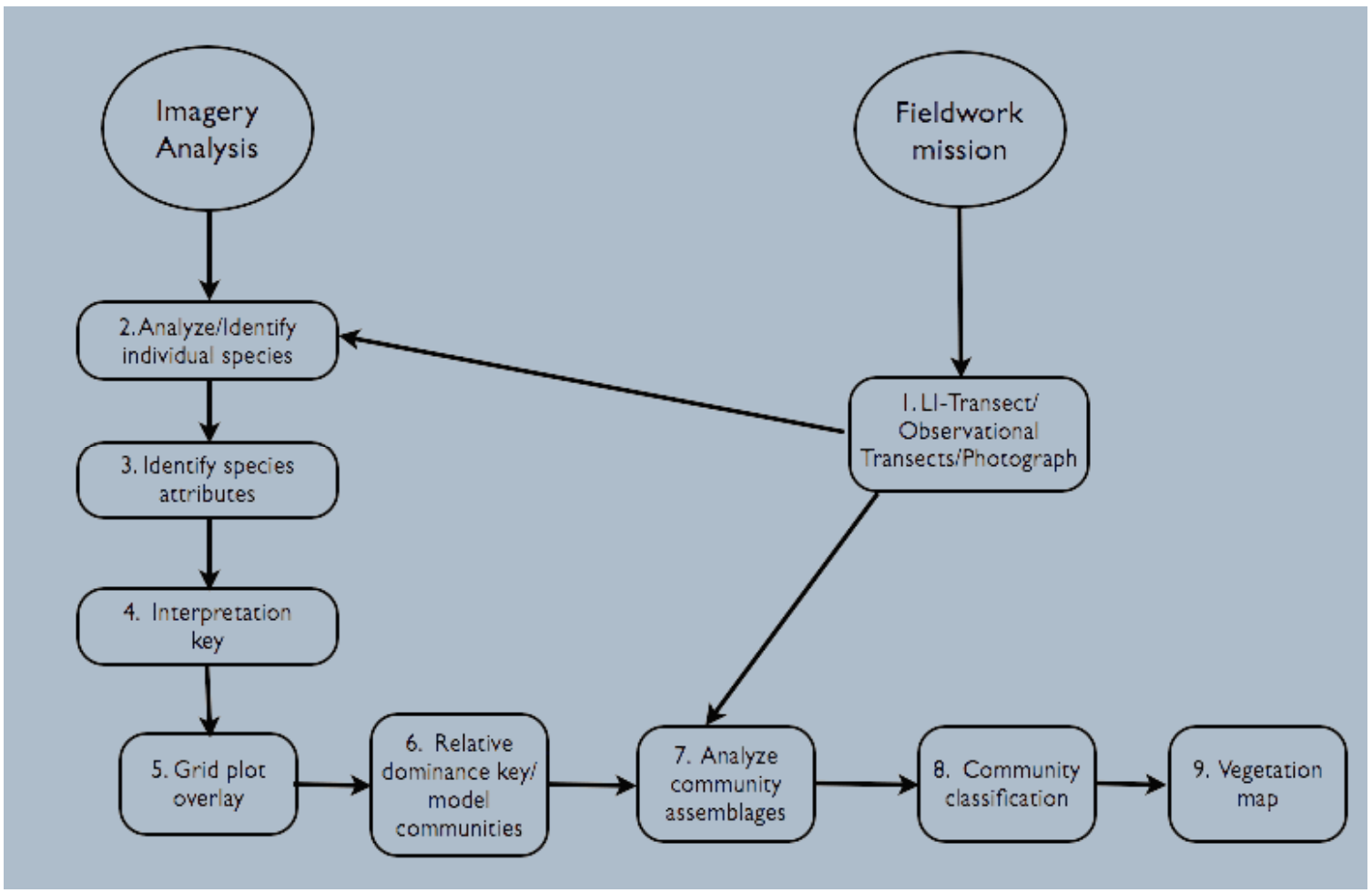

Figure 2. Methodological framework of the scientific process used in this study.

The field phase took place over 6 consecutive days from June $13^{\text {th }}$ to June $19^{\text {th }}, 2010$. There were 29 field transects for data collection of which 10 were line-intercept and an additional 19 "observational" transects were conducted via boat (Figure 3). The study area was documented by 165 photos visually recording each field location and all 29 points were georeferenced using a Garmin ${ }^{\circledR}$ GPS unit. 


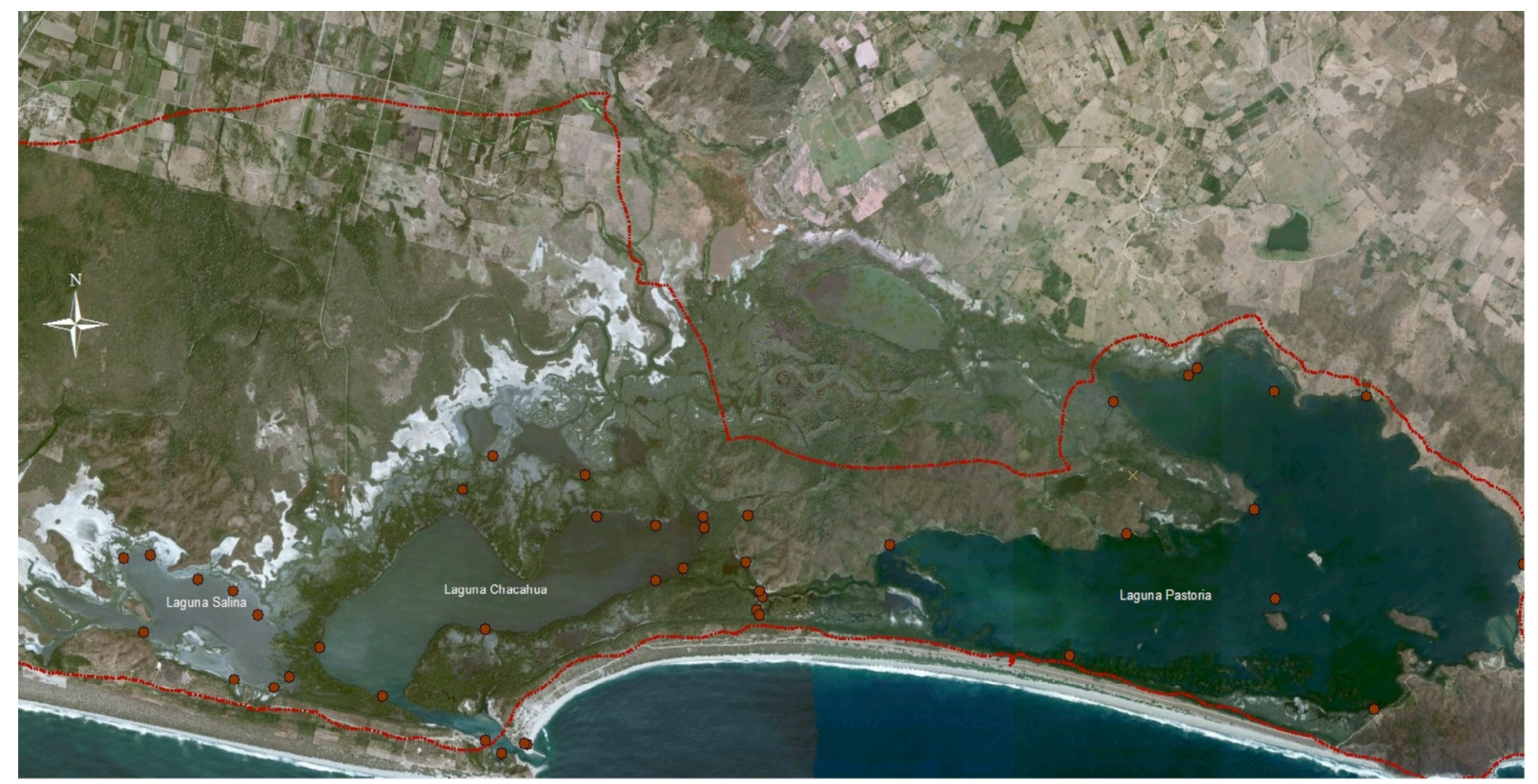

Figure 3. Field transect locations indicated by GPS points. Solid line represents park boundary.

Line-intercept transects were arranged along a $60 \mathrm{~m}$ baseline that ran parallel to the shore. The transects intersected the baseline every 10 meters at perpendicular angles to the shore and running $5 \mathrm{~m}$ in opposite directions (10 meters total length) (Figure 4$)$. This technique is important to alleviate sample bias that could occur from positioning inside a typical mangrove zonation, parallel to the shore. Typically in a mangrove forest, it is desired that transects run perpendicular to the shoreline to correct for the mangrove zonation pattern. For each transect, Frequency and DBH were recorded. From these measurements Basal Area and Relative Dominance could be calculated. In addition, age class and physiognomic character were determined for the stand at each location. 


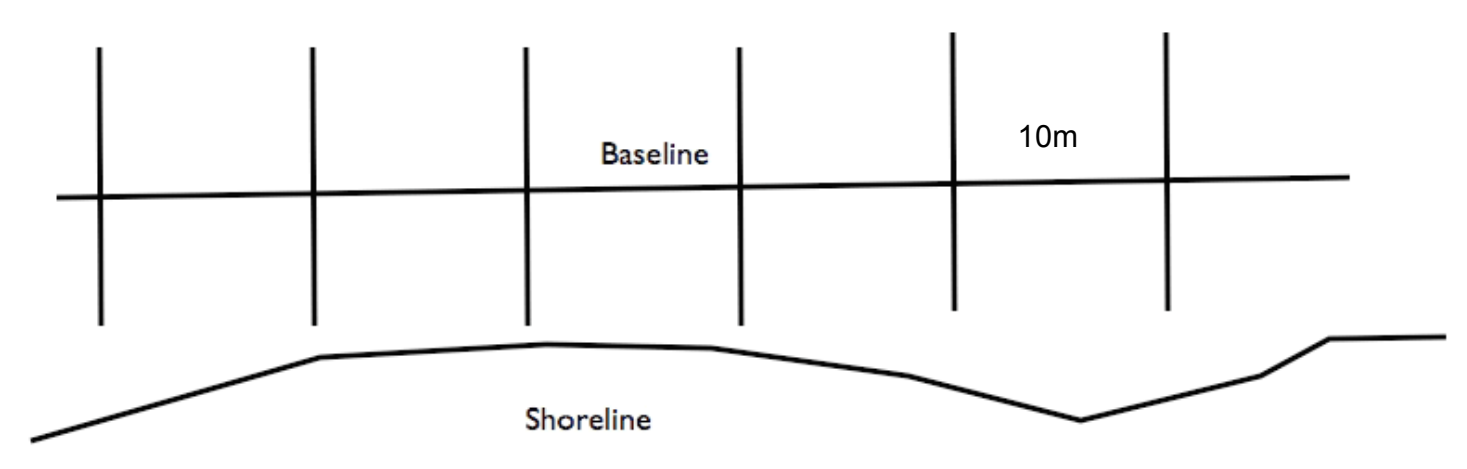

Figure 4. Example of transect design. Baseline was $60 \mathrm{~m}$ in length. Perpendicular transects were $10 \mathrm{~m}$.

The observational transect was methodology adopted from California Native Plant Society Rapid Assessment protocol and is a useful strategy in areas where access is difficult or funding and time are limited for a particular study. Stand structure and composition were the primary attributes of data collection for these transects. The presence or absence of each species, stand physiognomy, age class and relative abundance estimations were recorded.

For the laboratory phase of this study, high resolution imagery was provided by Bing ${ }^{\mathrm{TM}}$ Aerial Imagery through a license with ESRI, a Geographic Information Systems technology company. The aerial imagery was uploaded to Arcmap 10.0 GIS for visual analysis and creation of the vegetation map. The GPS data from the 29 field locations was also uploaded to the GIS and georeferenced into the aerial imagery. The process for image interpretation is in part adapted from Verheyden and colleagues' Image Interpretation Key (2003) for mangroves and can be explained in the following steps:

1. Individual trees were identified using the GPS locations and field data and 
photographs.

2. Image attributes based on color value, texture and shape were determined for each species (Table 2) as modified from Verheyden (et al. 2003), and at image scales ranging between 1:800 and 1:5,000.

3. To train the observer to recognize and define the natural boundaries of each plant community, a sampling grid was overlaid onto the aerial imagery, using the Fishnet Data Management tool in ArcMap 10. The grid was made up of $100 \mathrm{mx} 100 \mathrm{~m}$ cells, representing sampling plots and numbered 1-16,000 (Figure 5).

4. Using a random number table generated in Microsoft Excel®, 20 plots were located throughout the mangrove extent of Chacahua National Park. Note: random number plots not within the extent of the mangrove forest (i.e. located in a municipality, agricultural area or mixed vegetation) were considered "out of area" and not included in the analysis.

5. The plot chosen by the random number generator acted as the central point whereby the cells connected to the central cell were then included to form a block of $9,100 \mathrm{~m} \times 100 \mathrm{~m}$ plots for a total area of $300 \mathrm{~m} \times 300 \mathrm{~m}$ (Figure 5).

6. Using the species attribute key from step 2, the relative frequency of each species was recorded and an estimated relative cover value assigned. Frequency is a key measurement for defining the boundaries of a plant community as it is 
especially sensitive to changes in spatial arrangement (Elzinga, Salzar and Willoughby, 1998). Using larger plots in vegetation mapping allows "true" changes in spatial arrangement to be detected, rather than a spot of natural variability in the community composition. Verification from field data and photographs was used in the training.

7. Once the observer became familiar with the boundary decisions of the plant communities, the grid was removed and community classification could begin. It is important to use the same observer through the entire process to limit bias.

Table 2. Attributes for determining species identity in imagery analysis.

\begin{tabular}{lccc}
\hline Species & Shape & Color & Texture \\
\hline Rhizophora mangle & symmetrical, cauliflower & dark green, blue green & coarse \\
Laguncularia racemosa & irregular, scattered, striated & lime green to brown & coarse/fuzzy \\
Avicennia germinans & rectangular to irregular & blue grey,silver & fine/fuzzy \\
& & & \\
Conocarpus erectus & round, striated & grey green/brown & course/spotty \\
\hline
\end{tabular}




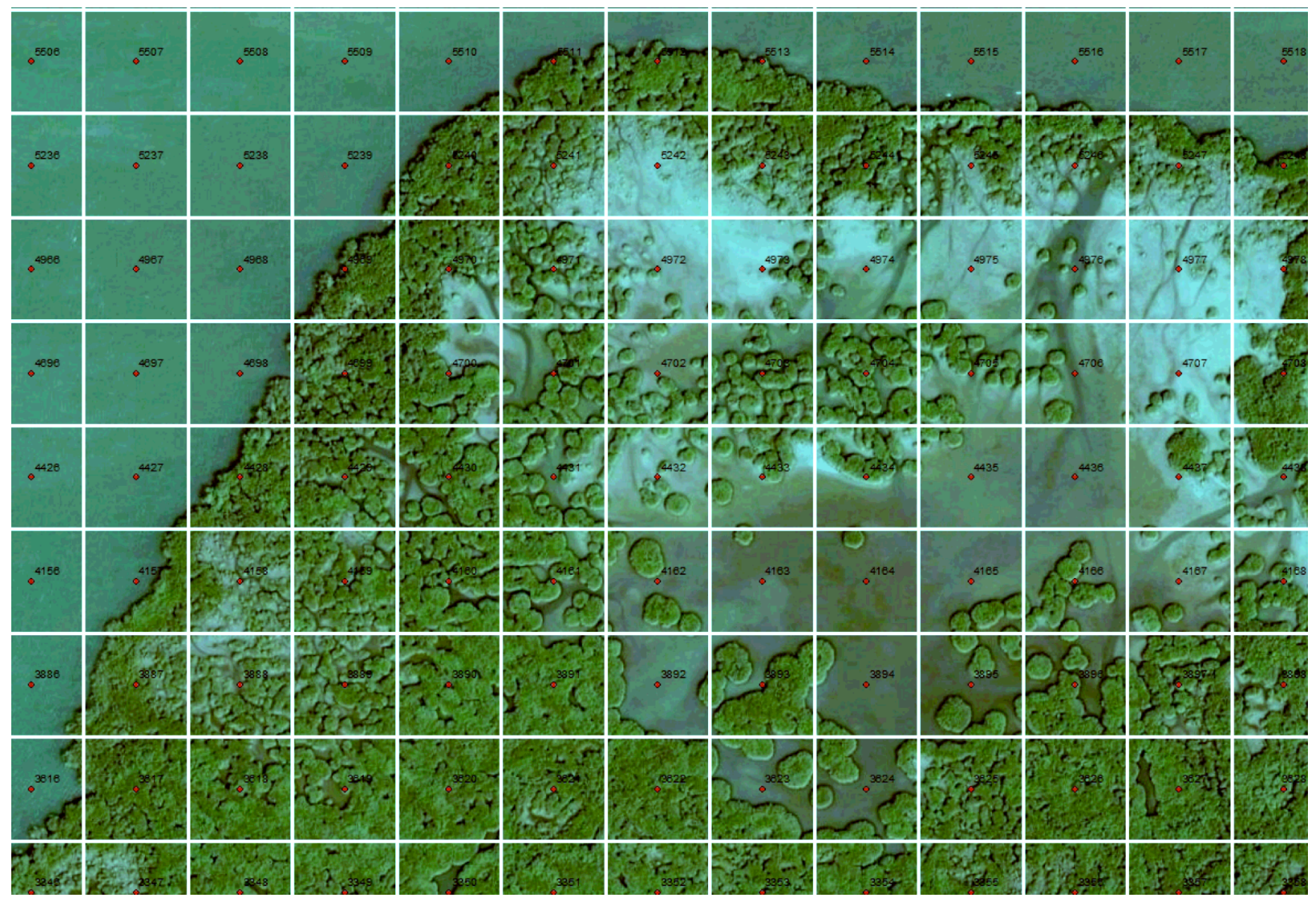

Figure 5. Grid Pot analysis using random numbers. Each square is $100 \mathrm{~m} \times 100 \mathrm{~m}$.

\section{Community Classification}

Relative density was not calculated for the observational transects or image grid plots because the comparison of these values to the relative density values of the field transects was shown by the use of the $G$-test in Verheyden and colleagues' study to be insignificant and thus incomparable. Using relative dominance values derived from field transects, estimated dominance from the observational transects, and the sum of the relative frequency and cover values from the grid analysis provided more comparability. When all 3 measures gave the same dominance order, these regions were compared for similarities. Any similarity in overall spatial pattern, was noted as a 'community attribute' and these regions then served as "models" for analyzing and detecting variations in vegetation structure throughout the mangrove meta-community. This is 
very similar to creating training samples in a supervised classification using satellite imagery and analysis software.

Classification nomenclature was decided by age class, genus (in order of dominance), and the Lugo-Snedaker typology (hammock, basin, overwash, etc.) Because each species is also in a separate genus, the nomenclature is given only as the genus name not including the species due to text restrictions in $\operatorname{ArcGIS}{ }^{\circledR}$. In regions where dominance varies through multiple species nomenclature would be: AGE_GENUS1_GENUS2_GENUS3_PHYS, in order of dominance value. In an area where 1 species is dominant and the other two species are in close proportions it is labeled as: AGE_GENUS_MIX_PHYS. In areas where one species is dominant (more than $80 \%$ ) the nomenclature is then AGE_GENUS_PHYS. Age class was divided between 'juvenile' ( $<10 \mathrm{yrs})$ and 'mature' (10 or $>10 \mathrm{yrs})$. The nomenclature also includes 'mixed age' for areas where age appeared inconsistent. Seedling data was not included in the classification as it was not considered an attribute of present community structure. 
A total of 13 distinct mangrove communities were identified for Laguna

Chacahua National Park (Figure 6), classified as the following:

Juvenile_Avicennia_fringe, Juvenile_Avicennia_Laguncularia_fringe,

Mixed_Age_Laguncularia_hammock, Mature Laguncularia_basin,

Mature_Avicennia_fringe, Mature_Avicennia_Conocarpus_fringet,

Mature_Rhizophora_Mix_fringe, Mature_Rhizophora_hammock,

Mixed_Age_Rhizophora_Laguncularia_hammock, Mature_Rhizophora_overwash.

In this study, Rhizophora mangle was the overall most significant species being dominant across 1,218 hectares followed by Laguncularia racemosa in 589.6 hectares and lastly Avicennia germinans in 495 hectares (Figure 7). In areas where Rhizophora mangle coexists with the other mangrove species, it is usually the most dominant with highest frequency and dominance. It was also observed that typical mangrove zonation between Avicennia germinas and Laguncularia racemosa, is not present in Chacahua, as the two species are most often found interspersed in random fashion. However, Rhizophora was consistently in the most seaward position where all three coexisted. Unfortunately, Conocarpus was found in only 1 field transect, 1 observational transect and in only two areas on the grid plots. This is most likely due to over-harvesting as discussed previously (Figure 8). The 3 main lagoons in the park varied in the mangrove forest extent and number of communities each contained. Laguna Chacahua and Laguna Salina both contained 8 of the fourteen community types (Figure 5) (Figure 6), while Pastoría was the least diverse with 7 communities (Figure 7). This is most likely due to less tidal flux (causing more consistent salinity and $\mathrm{pH}$ ) and more abrupt rise in elevation beyond the shoreline. Of the Lugo-Snedaker forest typologies, the Hammock forest dominated, covering 1,550.6 hectares, Fringe forests were second in line covering \# hectares while Overwash forest types were found in only one region of Laguna Pastoría covering \# 
hectares. True basin forests within the park were rare and found to occur in one small area of \# hectares. However it should be noted there are large basin forests directly to the north central region of Chacahua that are outside of park boundaries. Of the community classifications, Mixed age Rhizophora_Laguncularia hammock covered the most area with 668 hectares. 


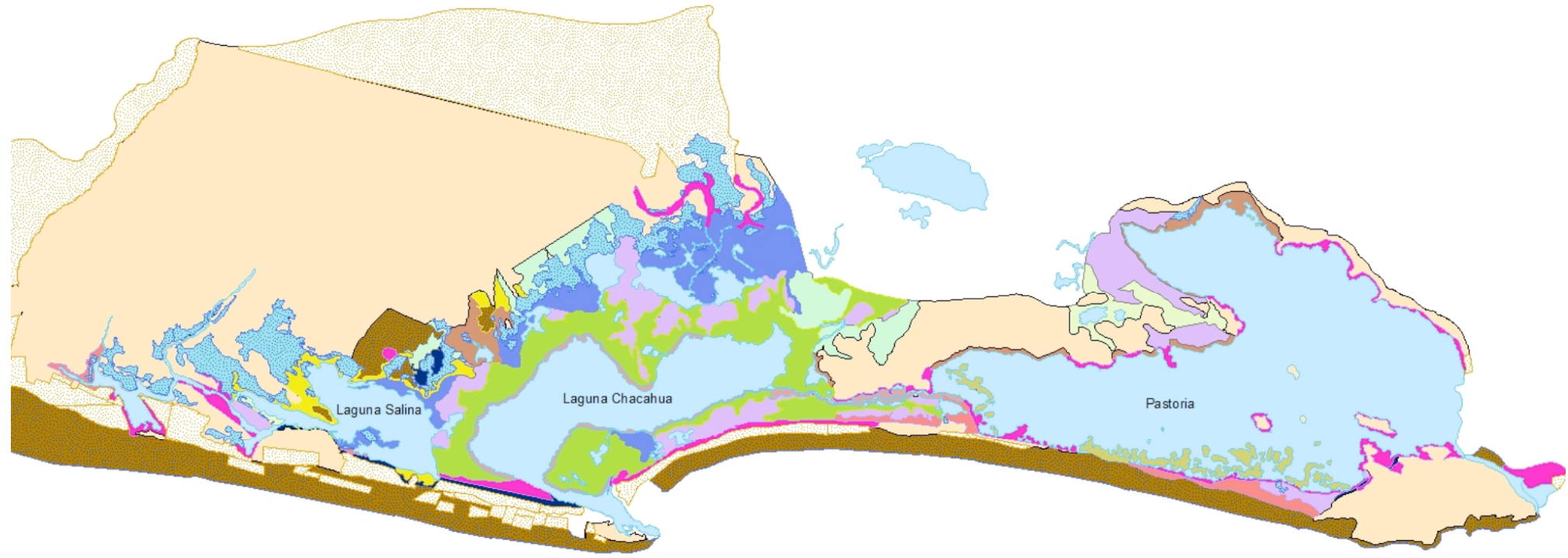

Mangrove Communities

Parque Nacional Lagunas de Chacahua

\section{Classification}

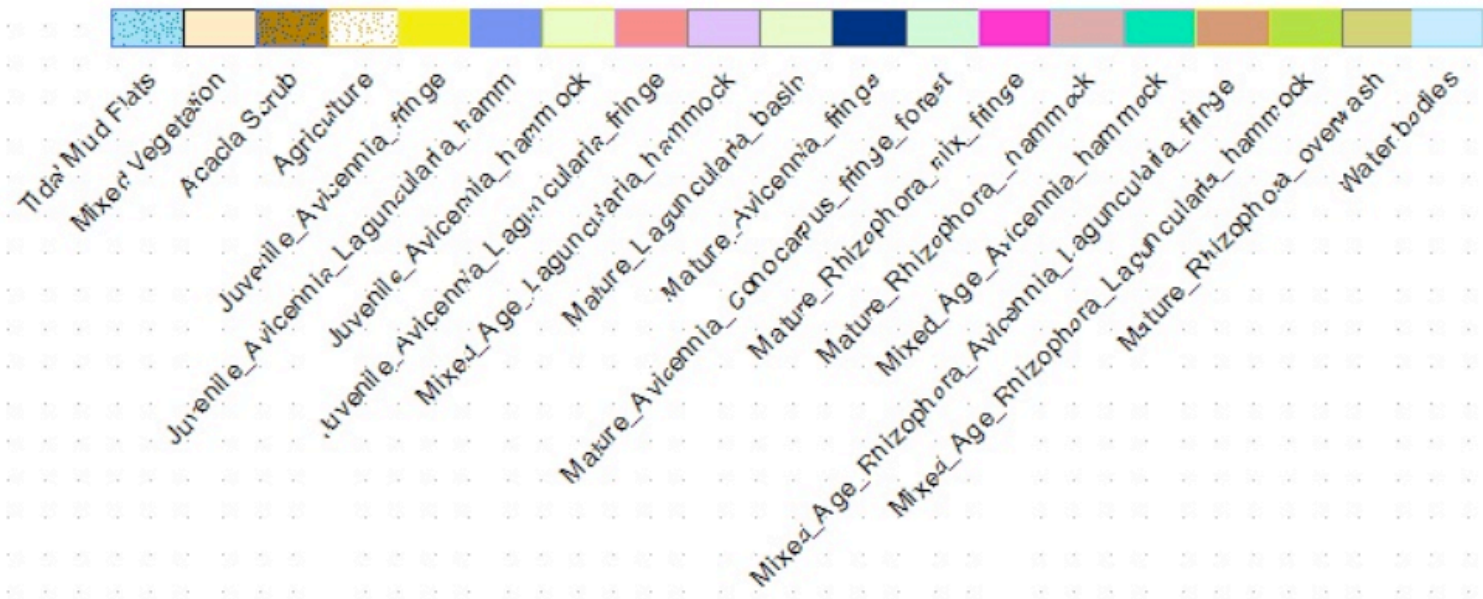

Figure 6. The nineteen cover classes of Laguna Chacahua National Park. Fourteen of which are mangrove vegetation types. 


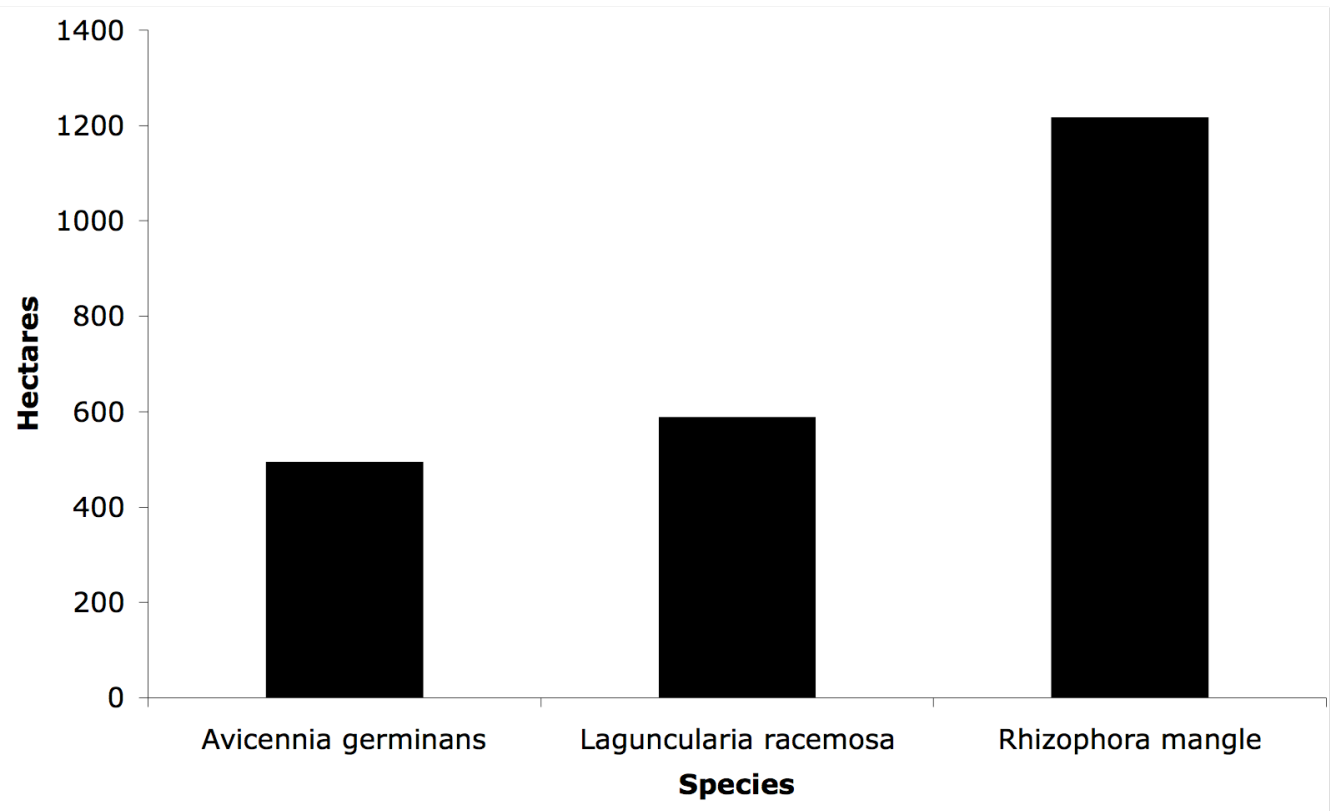

Figure 7. Number of hectares in which each species was dominant.

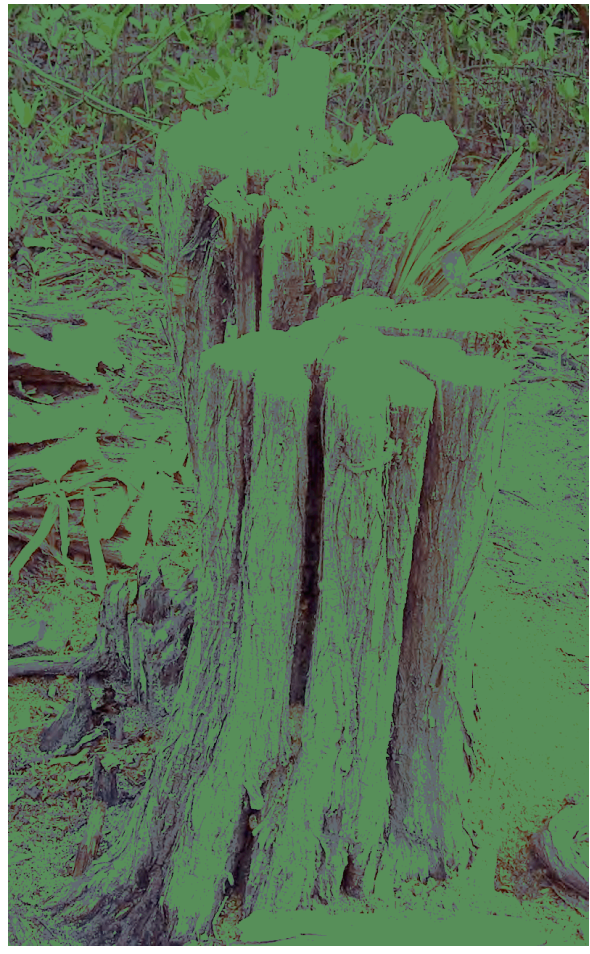

Figure 8. Harvested Conocarpus erectus found at site S12A. 


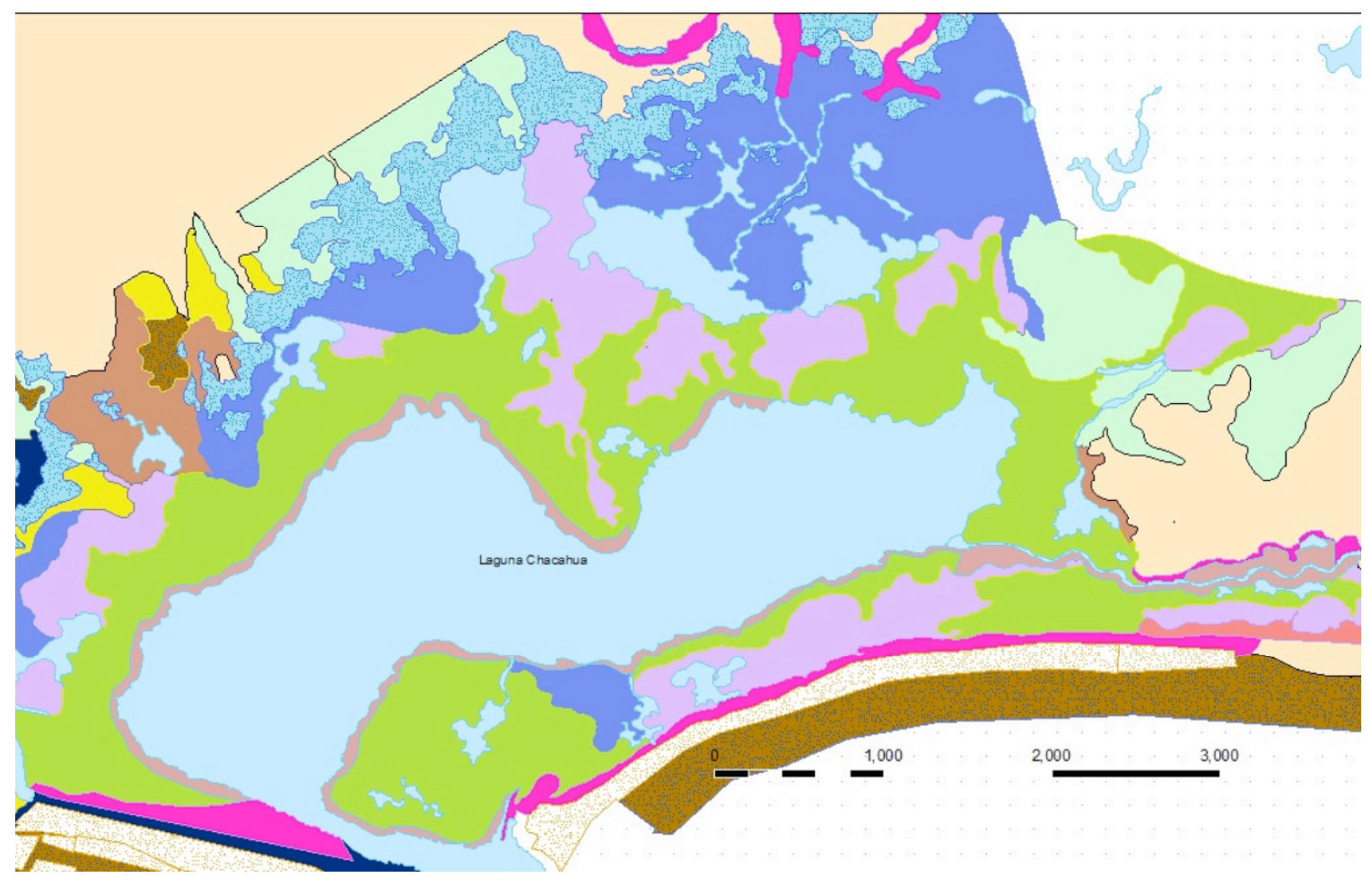

\section{Mangrove Communities}

\section{Parque Nacional Lagunas de Chacahua}

\section{Classification}

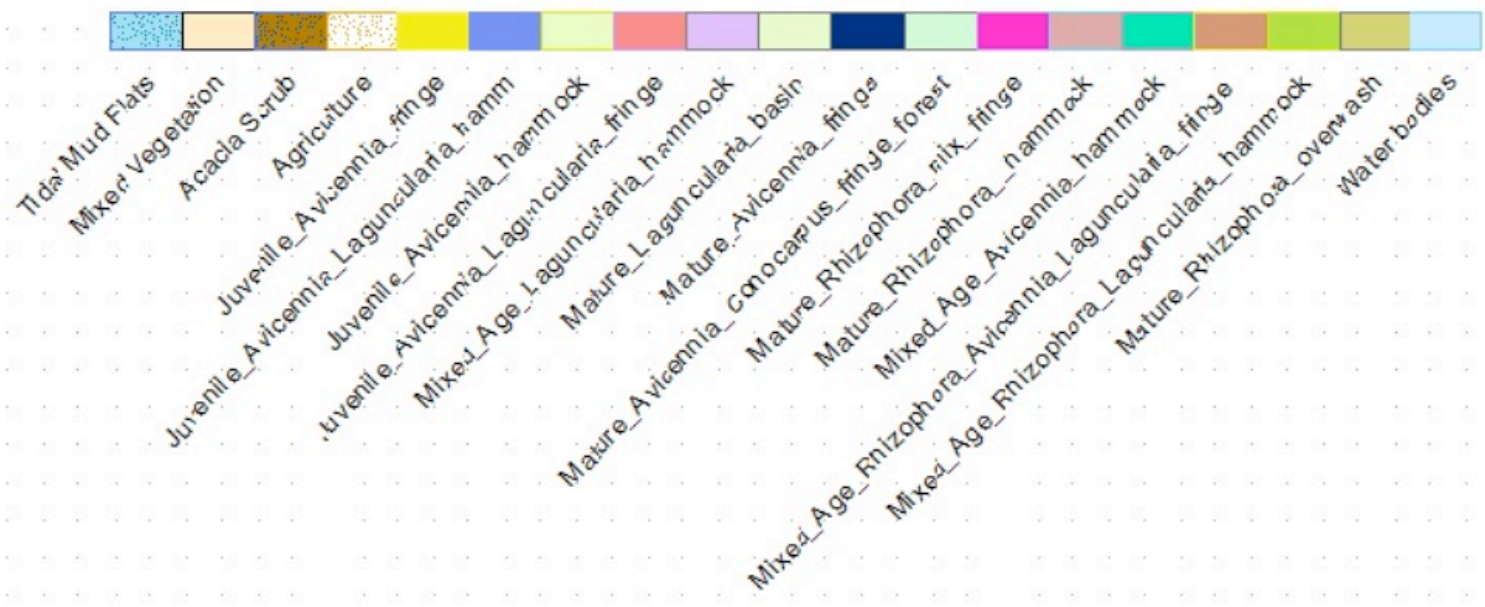

Figure 9. Vegetation classes of Laguna Chacahua. Nine of the fourteen classes were observed. 


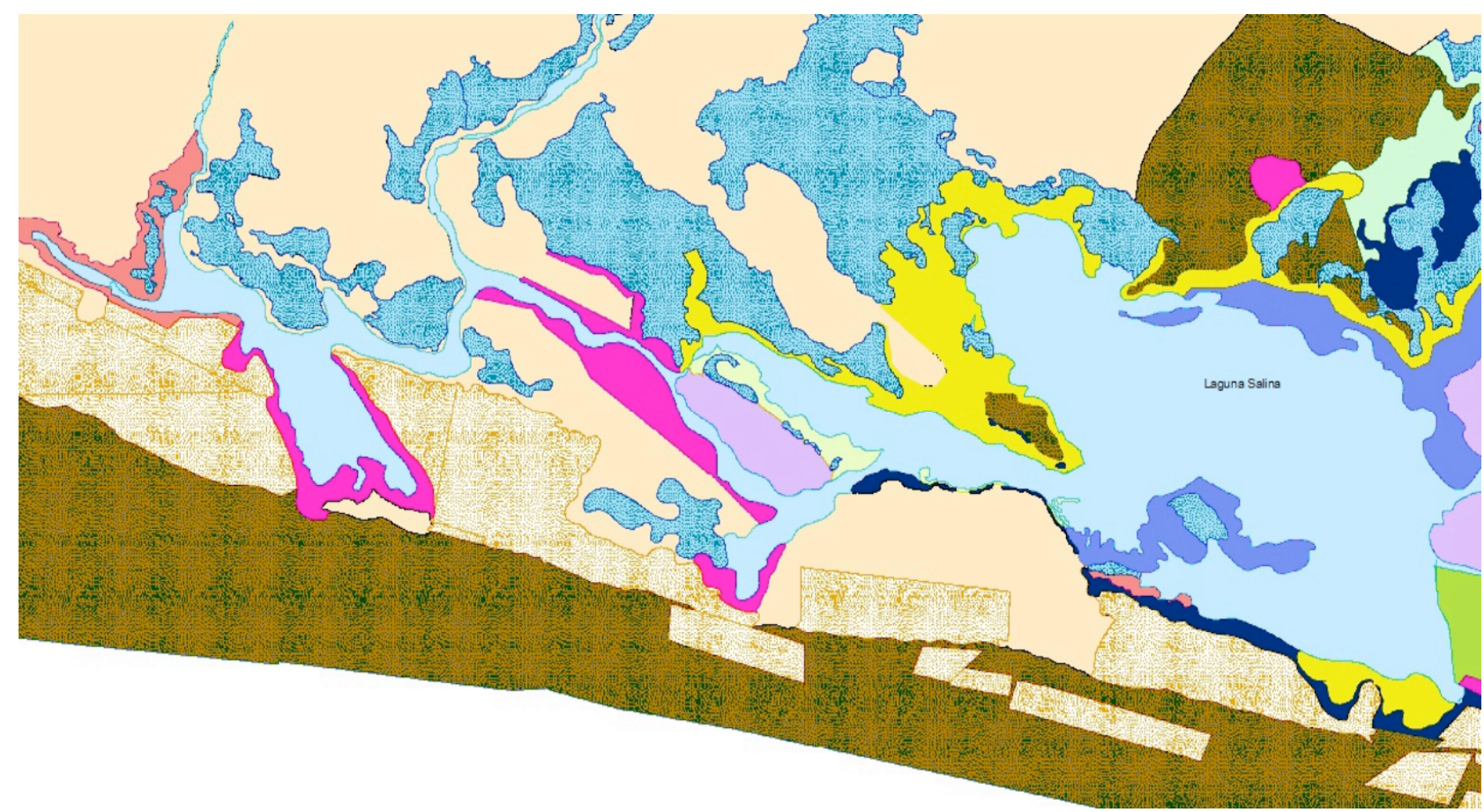

Mangrove Communities

Parque Nacional Lagunas de Chacahua

\section{Classification}

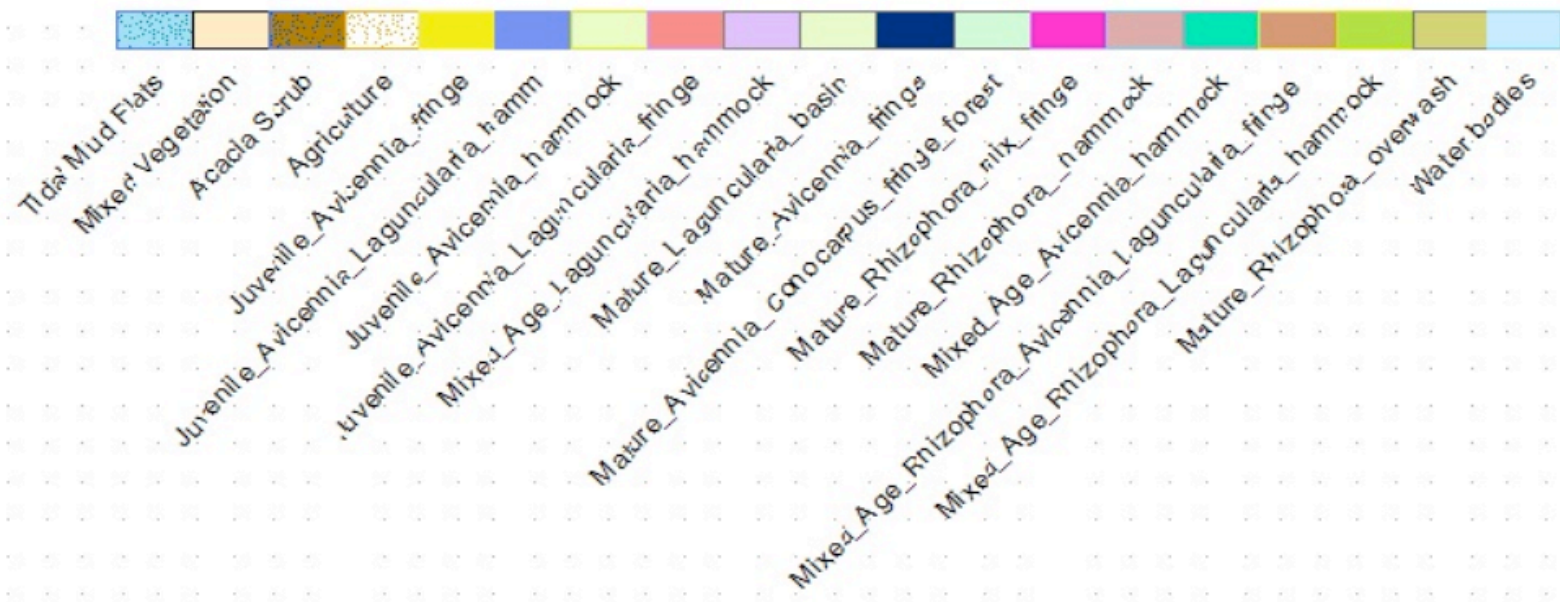

Figure 10. Vegetation classes of Laguna Salina. Ten of the fourteen classes were found in this lagoon. 


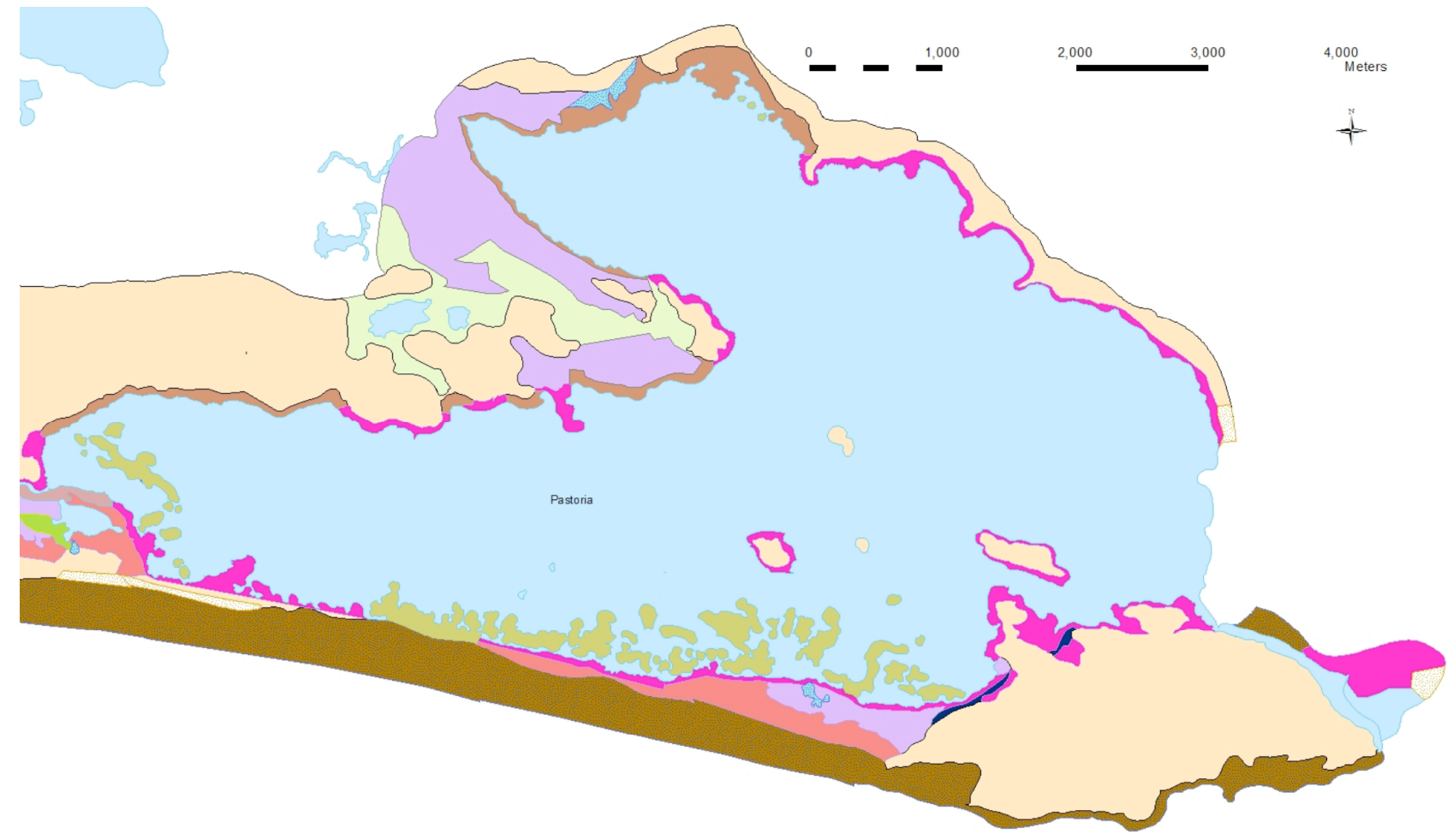

Mangrove Communities

Parque Nacional Lagunas de Chacahua

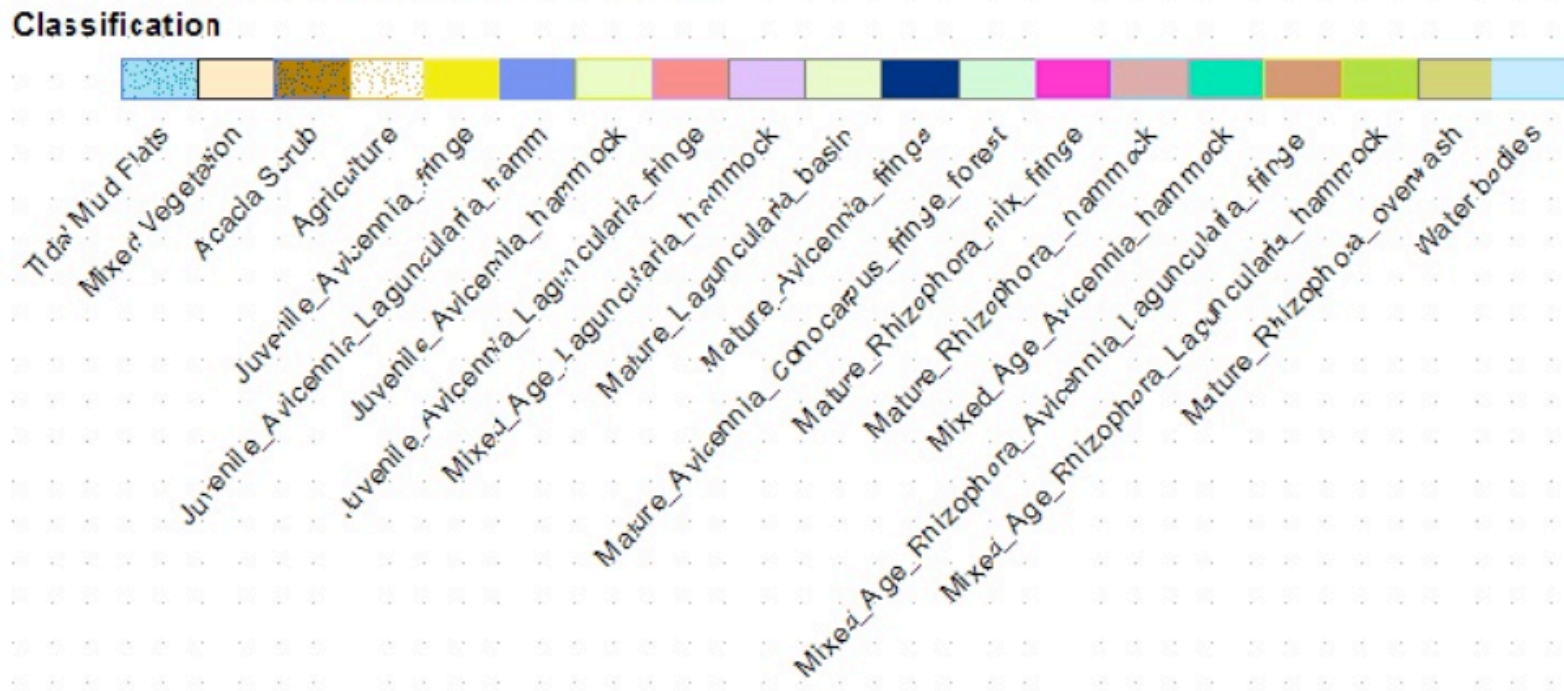

Figure 11. Vegetation classes of Laguna Pastoria. Seven of the fourteen mangrove classes were recorded in this lagoon. 


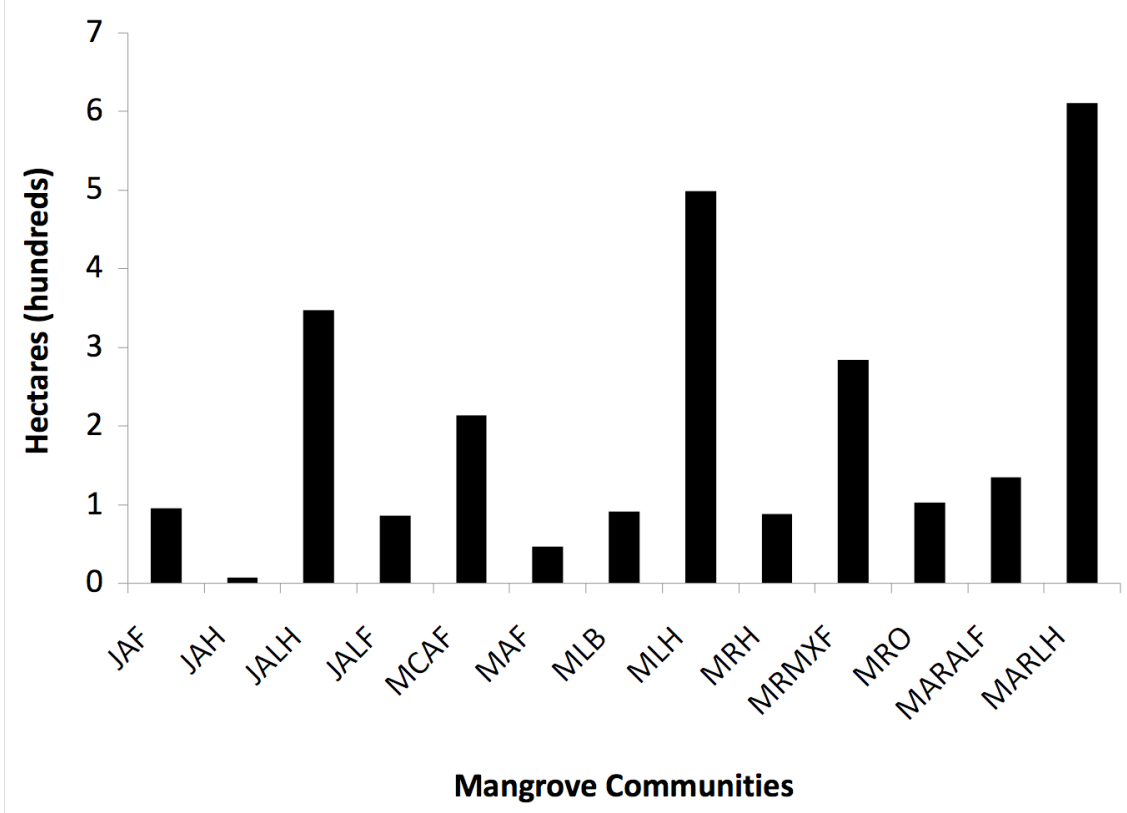

Figure 12. Mangrove community coverage in Hectares. JAF= Juvenile Avicennia fringe, JAH= Juvenile Avicennia hammock, JALH= Juvenile Avicennia Laguncularia hammock, JALF= Juvenile Avicennia Laguncularia Fringe, MCAFF= Mature Conocarpus Avicennia Fringe Forest, MAF=, Mature Avicennia Fringe, MLB= Mature Laguncularia Basin, MLH= Mature Laguncularia Hammock, MRH= Mature Rhizophora Hammock, MRMXF= Mature Rhizophora mix Fringe, MRO= Mature Rhizophora Overwash, MARALF= Mixed Age Rhizophora Avicennia Laguncularia Fringe, MARLH= Mature Avicennia Rhizophora Laguncularia Hammock.

Several advantages and disadvantages exist in using Bing ${ }^{\text {TM }}$ imagery. One disadvantage of using Bing ${ }^{\mathrm{TM}}$ imagery is that there is no indication of which satellite or orthophoto provider is contributing the imagery. Scale is accurately provided through GIS but resolution can only be estimated. For this study, the imagery was estimated to be at a $1 \mathrm{~m}$ resolution (pers. Comm. David Yun, GISP, MS, 07/14/11). Because no attribute data is being provided along with the imagery the only way to use this service for vegetation mapping is through visual interpretation. However interagency cooperation makes the use of this mapping service more cost-effective than purchasing satellite imagery through other providers, as many academic institutions hold licenses with ESRI. 
In addition, students can obtain 1 free year of ArcGIS and thus, many users now have access to Bing ${ }^{\mathrm{TM}}$ imagery. The reliability of using Bing ${ }^{\mathrm{TM}}$ aerial imagery was shown in this study. The difference of relative dominance values between field transects and imagery grid plots was insignificant showing that community classifications can be constructed with this methodology (Figure 13).

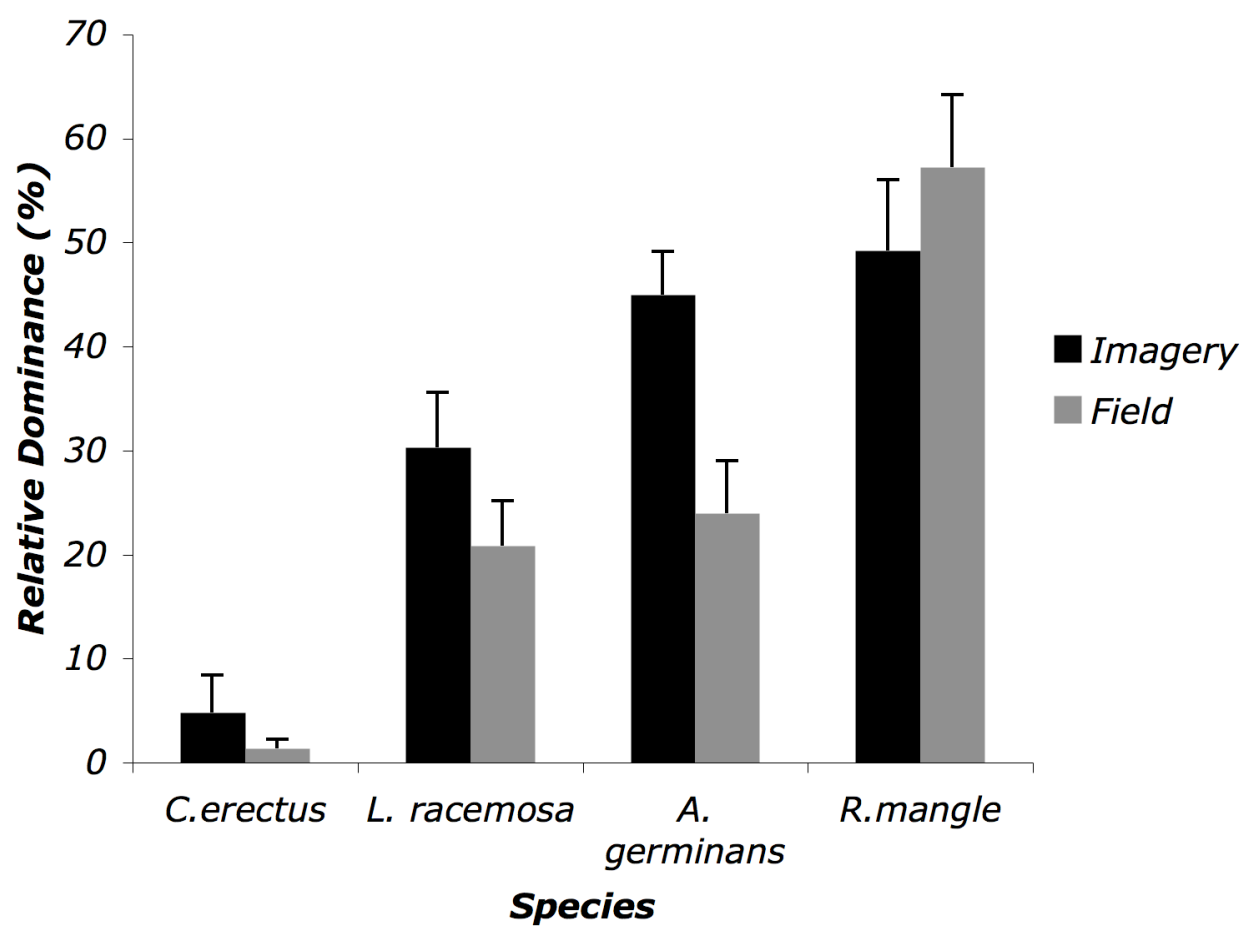

Figure 13. Comparison of field and grid plot relative dominance values to determine community classification. In both techniques $R$. mangle, is the most dominant followed by, A. germinans, $L$. racemosa and lastly Conocarpus erectus. Error bars represent standard error of the mean. 


\subsection{CONCLUSION}

The purpose of this study was: (1) to convey the need for finer scale, more detailed mapping and classification of mangrove forests for the purpose of management and (2) to demonstrate the potential use of Bing ${ }^{\mathrm{TM}}$ aerial imagery in vegetation analysis. One of the first vegetation studies to utilize Bing TM aerial imagery for analysis, the level of detail in the imagery was sufficient to identify 14 distinct forest communities using the visual interpretation method. Combining age-class, biological data (frequency, coverage and dominance measures), with Lugo-Snedaker typology based on physiognomic features at this level of detail is the first of its kind for Mexican mangroves, however, several other mangrove mapping studies have been conducted in Mexico using broader scale imagery and analysis for various purposes. Satellite imagery with band data provides results in a shorter time than human visual analysis however it lacks the same level of detail that is necessary for maps used in a day-to day management scenario. For example, a study performed by Sulong and colleagues (2002) also found 14 mangrove forest in communities at their study site of the Cukai River in Malaysia using aerial photography at a 1:5,000 scale with visual interpretation. However when they analyzed the same location using Landsat TM $(30 \mathrm{~m})$ imagery with a supervised classification, the number of classes dropped to 7 . While multispectral imagery and recently hyperspectral imagery have improved, there are special challenges with reflectance values in a wetland environment when identifying to a species level using computer software (Adam et al., 2009). Visual interpretation proves highest accuracy in these cases. In particular, species poor-systems such as mangrove forests require more intricate techniques to decipher the variance in community composition. Day-to-day management needs require highly detailed and geographically precise records of the managed vegetation. This study provides combines classic biological principles with new methodology to create a new 
process for mapping of mangrove vegetation. With the imperative need to conserve this special ecosystem, designing new, cost effective ways of providing decision makers and environmental managers with useful tools that make monitoring more effective is absolutely essential to conservation in under-resourced regions. Vegetation maps, created by using readily available imagery software is the next step in meeting the needs of resource managers. 


\section{References}

Adam, E. Mutanga, O., Rugege, D. (2009). Multispectral and hyperstepectral remote sensing for identification and mapping of wetland vegetation: a review. Wetlands Ecological Management. Published Online: DOI 10.1007/s11273-009-9169-z.

Alpert, P. (1996). Integrated conservation and development projects.

BioScience, 46 (11), 845-855.

Balsamo, R.A., and W.W. Thomson. (1995). Salt effects on membranes of the hypodermis and mesophyll cells of Avicennia germinans. American Journal of Botany, 82 (4), 435-440.

Barletta-Bergan, A., Barletta, M., Saint-Paul, U., (2002a). Community structure and temporal variability of ichthyoplankton in North Brazilian mangrove creeks. Journal of Fish Biology, 61, 33-51.

Bauer, H.L. (1943). The Statistical Analysis of Chaparral and Other Plant Communities by Means of Transect Samples. Ecology, 46, 45-60.

Blasco, F., Gauquelin, T., Rasolo, M., Denis, J., Aizpuru, M., Caldairou, V. Recent advances in mangrove studies using remote sensing data. Marine Freshwater Research, 49, 287-296.

Cintrón, G., Lugo, A., Martinéz, R. (1980). Structural and Functional Properties of Mangrove Forests. Symposium Signalling the Completion of the 'Flora of Panama'. Panama City, University of Panama. (UNESCO Library)

Contreras E. F., 1993. Ecosistemas Costeros Mexicanos.1st. edition UAM-Unidad Iztapalapa. México D.F. 415 pp.

Crona, B.I., Rönnbäck, P., (2007). Community structure and temporal variability of juvenile fish assemblages in natural and replanted mangroves, Sonneratia alba of Gazi Bay, Kenya. Estuarine and Coast and Shelf Science, 74, 44-52.

Dahdouh-Guebas, F. (2002). The use of remote sensing and GIS in the sustainable management of tropical coastal ecosystems Environment, Development and Sustainability 4(2), 93-112.

Duke, N., Ball, M., Ellison, J., (1998). Factors influencing biodiversity and distributinal gradients in mangroves. Global Ecology and Biogeography Letters, 7, 27-47.

Elzinga, C., Salzar, D., Willoughby, J. (1998). Measuring and Monitoring Plant Populations. (BLM Technical Reference 1730-1).

Gao, J. (1998). Hybrid method toward accurate mapping of mangroves in a marginal habitat from SPOT Multispectral data. International. Journal. Remote Sensing, 
19, 1887-1899.

Giri, C., Ochieng, E., Tieszen, L. L., Zhu, Z., Singh, A., Loveland, T., Masek, J. and Duke, N. (2011), Status and distribution of mangrove forests of the world using earth observation satellite data. Global Ecology and Biogeography, 20, 154-159.

Hernández, C. and Espinosa, G. (1999) Producción y Aprovechamiento del Mangle Conocarpus erectus en Barra de Tecoanapa Guerrero, México. Bioropica, 31(1), 121-134.

Hernández Cornejo, R., Koedam, N., Ruiz Luna, A., Troell, M., Dahdouh-Guebas, F., (2005). Remote sensing and ethnobotanical assessment of the mangrove forest changes in the Navachiste-San Ignacio-Macapule lagoon complex, Sinaloa, Mexico. Ecol. Soc. 10 (1) art 16.

-Garcia, M. A. \& Frejomil, E. P., (2000). Las dependencies regionales de los asentamientos humanso localizados en el arque nacional "Lagunas de Chacahua", Oaxaca. Investiganciones Geografía, Boletin del Instituto de Geografía, 41, UNAM.

Jiménez, J. (1981). The Mangroves of Costa Rica: A Physiognomic Characterization. Coral Gables, Florida., University of Miami. 130 pp. (MS thesis.)

Kathiresan, K. and Bingham, B., (2001). Biology of mangrove and mangrove ecosystems. Advances in Marine Biology, 40, 81-251.

Kuchler, A., (1949). A Physiognomic Classification of Vegetation. Annals of the Association of American Geographers, 39(3), 201-210.

Kuchler, A., (1967). Vegetation Mapping. The Ronald Press Company, New York, pp. 472.

Kuchler, A., Zonneveld, I.S. (Eds.), (1988). Vegetation Mapping, vol 10. Handbook of Vegetation Science. Kluwer Academic Publishers, Dordrecht, pp. 625.

Kuenzer, C., Bluemel, A., Gebhardt, S., Vo Quic, T., Dech, S. (2011). Remote Sensing of Mangrove Ecosystems: A Review. Remote Sensing, 3. 878-928.

Lillesand, T.M. and Kiefer, R.W. (1994) Remote Sensing and Image Interpretation, New York, JohnWiley \& Sons, Inc, pp. 736.

López-Portillo, J. and Ezcurra, E. (1989). Zonation in mangrove and salt marsh vegetation at Laguna de Mecoacán, México. Biotropica, 21, 107-114.

Los Manglares de México: estado actual y establecimiento de un programa de monitoreo a largo plazo: 1ra. etapa. (2007). Informe final del Proyecto DQ056. CONABIO pp. 70. 
Lugo, A. E., and S. C. Snedaker. (1974). The Ecology of Mangroves. Annual Review of Ecology and Systematics 5, 39-64.

Martínez, R., Cintrón, G., Encarnación, L. (1979). Mangroves in Puerto Rico: A Structural Inventory. (Final Report, Office of Coastal Zone Management, NOAA.) Department of Natural Resources, San Juan, Puerto Rico. 149 pp

Meza Diaz, B.; Blackburn, G.A. (2003). Remote sensing of mangrove biophysical properties: Evidence from a laboratory simulation of the possible effects of background variation on spectral vegetation indices. International Journal of Remote Sensing, 24, 53-73.

Moore, J. J., Fitzsimons, S. J., Lambe, E., White, J., (1970). A comparison and evaluation of some phytosociological techniques. Vegetatio, 20, 1-19.

Muller, E. (1997). Mapping riparian vegetation along rivers: old concepts and new methods. Aquatic Botany, 58, 411-437.

Nagelkerken, I., Roberts, C.M., van der Velde, G., Dorenbosch, M., van Riel, M.C., Cocheret de la Moriniere, E., Nienhuis, P.H., (2002). How important are mangroves and seagrass beds for coral-reef fish? The nursery hypothesis tested on an island scale. Marine Ecology Progress Series 244, 299-305.

Ogden, J.C., (1997). Ecosystem interactions in the tropical coastal seascape. In: Birkeland, C. (Ed.), Life and Death of Coral Reefs. Chapman \& Hall, London, pp. 288-297.

Pool, D. J., Snedaker, S.C., Lugo, A . E . (1977). Structure of Mangrove Forests in Florida, Puerto Rico, Mexico and Costa Rica. Biotropica, 9(3), 195-212.

Ramsey, E.W., Jensen, J.R. (1996). Remote sensing of mangrove wetlands: Relating canopy spectra to site-specific data. Photogrammatric. Engineering and Remote Sensing, 62, 939-948.

Robertson, A.I., Duke, N.C., (1990.) Mangrove fish communities in tropical Queensland, Australia: spatial and temporal patterns in densities, biomass and community structure. Marine Biology, 104, 369-379.

Saenger P,Hegerl EJ,Davie JDS. (eds)., (1983). Global status of mangrove ecosystems. The Environmentalist 3(3).

SchimperA, . F. W. (1903). Plant Geography on a Physiological Basis. Oxford: Oxford Univ. Press. 839 pp

Serafy, J.E., Araújo, R.J. (eds.), (2007). Proceedings of the 1st International Symposium on Mangroves as Fish Habitat. Bulletin Marine Science (special issue) 80, 451-935. 
Smith, S.M., Snedaker, S.C. (1995). Salinity Responses in Two Populations of

Viviparous Rhizophora mangle L. Seedlings. Biotropica, 27(4), 435-440.

Sulong, H., Mohd-Lokman, K., Mohd-Tarmizi, K., Ismail, A. (2002). Mangrove Mapping Using Landsat Imagery and Aerial Photographs: Kemaman District, Terengganu, Malaysia. Environment, Development and Sustainability 4, 135-152.

The Worlds Mangroves 1980-2005. FAO Forestry Paper 153. Food and Agricultural Organization of the United Nations, Rome, 2007. ISBN: 978-92-5-105856-5

Tomlinson, P. B. 1986. The botany of mangroves. Cambridge University Press, Cambridge, United Kingdom.

Vaiphasa, C., Skidmore, A., de Boer, W. F., (2006). A post-classifier for mangrove mapping using ecological data. Journal of Photogrammetry \& Remote Sensing, 61 $1-10$.

Vaiphasa, C., Suwit, O., Vaiphasa, T., Skidmore, A. (2005). Estuarine, Coastal and Shelf Science, 65, 371-379.

Valdez JI (1994) The vegetation of a mangrove forest in the Pacific coast of Mexico. Wageningen Agricultural University, Wageningen. (Masters thesis).

Valiela, V., Bowen, J. L., York, J. K. (2001). Mangrove Forests: One of the World's Threatened Major Tropical Environments. BioScience, 51(10), 807-815

Verheyden, A., Dahdouh-Guebas, F., Thomaes, K., De Genst, W., Hettiarachchi, S., Koedam, N., 2002. High-resolution vegetation data for mangrove research as obtained from aerial photography. Environment, Development and Sustainability 4(2), 113-133.

Waisel, Yoav. 1972. Biology of Halophytes. Academic Press, New York. 395 pgs.

Walters, B., Rönnbäck, P., Kovacs, J., Crona, B., Hussain, S.A., Badola, R., Primavera, J., Barbier, E., Dahdouh-Guebas, F. (2008). Ethnobiology, socio-economics and management of mangrove forests: A review. Aquatic Botany, 89, 220-236.

Watson, J. G. 1928. Mangrove forests of the Malay peninsula. Malayan Forest Records 6: $1-275$.

Wessman, C.A., Ustin, S.L., Curtiss, B., Gao, B.-C., (1991). A conceptual framework for ecosystem modeling using remotely sensed inputs. Proceedings of the 5 th International Colloquium: Physical measurements and signatures in Remote Sensing, 14-18 January 1991, Courchevel, France, ESA publications, ESTEC, Noordwijk, The Netherlands, pp. 777-782. 
